\title{
Incarcerated Activism During COVID-19
}

\author{
M. Eve Hanan*
}

\begin{abstract}
Incarcerated people have a notoriously difficult time advocating for themselves. Like other authoritarian institutions, prisons severely curtail and often punish speech, organizing, and self-advocacy. Also, like other authoritarian institutions, prison administrators are inclined to suppress protest rather than respond to the grounds for protest. Yet, despite impediments to their participation, incarcerated people have organized during the pandemic, advocating for themselves through media channels, public forums, and the courts. Indeed, a dramatic increase in incarcerated activism correlates with the onset of the COVID-19 pandemic.

Just as the COVID-19 pandemic highlights injustice in other areas of criminal legal practices, it reveals both the dangers of silencing incarcerated speech and the potential for prisoner self-advocacy. This essay discusses silencing and speech in carceral spaces during the COVID-19 pandemic, using a theory of political philosophy called epistemic injustice. The theory of epistemic injustice addresses how disfavored social groups are excluded from sharing knowledge in public conversations. The stifling of prisoner speech occurs in part because incarcerated people are deliberately separated from the outside world. But it also reflects their status as a stigmatized - and thus discreditedgroup. Even when their speech is heard, it is discounted as manipulative and untrustworthy.

Second, this essay argues that the self-advocacy efforts made by incarcerated people during the pandemic demonstrate the democratic value of their participation. Among the necessary predicates to meaningful change in criminal legal practices is the democratic participation of the targets of those practices, including suspects, criminal defendants, and prisoners. Their participation in the political sphere serves a vital democratic function the absence of which is felt not only in the authoritarian structure of prisons, but in the failure to enact widespread change to criminal legal practices.
\end{abstract}

* Associate Professor of Law, University of Nevada Las Vegas, JD Michigan Law School. I thank Kathryn Miller, Lea Johnston, and Jamelia Morgan for their careful reads of and comments on earlier drafts, and the Works in Progress Roundtable organized by the ABA Criminal Justice Section Academics Committee, in partnership with the AALS Criminal Justice Section and the Academy for Justice. I also thank my research assistant, Syanne Hines, for her assistance. 


\section{INTRODUCTION}

In early May of 2020, a person walking outside of the Bristol County Jail and House of Correction in Massachusetts could look up to see the words, "Help Us" written in soap on a window. ${ }^{1}$ Medically vulnerable detainees in the jail were already part of a class action lawsuit alleging that social distancing and other measures necessary to prevent the spread of COVID-19 were impossible within the crowded confines of the jail. ${ }^{2}$

As we see repeated in similar cases, the description of conditions offered by detainees and the jail's administrators differed significantly. In their declarations, detainees alleged departures from safety protocols, including beds placed three feet apart, a lack of sanitation supplies, a lack of protective equipment, failure to respond to sick calls, and exposure to staff displaying symptoms of COVID-19. ${ }^{3}$ The Bristol County Sheriff's Office disputed these claims, and countered that it had implemented safety protocols. ${ }^{4}$

Although some detainees had been released from Bristol County's jails and prisons after the lawsuit was filed, ${ }^{5}$ the jail unit was poised to erupt in protest. Detainees reported that staff took them to solitary confinement after telling them they would go to the medical wing, and others reported that the medical wing itself posed a health risk because of inadequate safety measures to prevent infection. ${ }^{6}$ As a result of these concerns, detainees refused to comply with orders to go to the medical wing. ${ }^{7}$ The standoff escalated: beds were overturned; the staff turned on the

1 Catherine E. Shoichet, After Violence Erupted in an ICE Detention Facility, a Message Left on the Window Said, "Help Us," CNN (May 22, 2020) https://www.cnn.com/2020/05/22 /us/icedetention-coronavirus-violence-hunger-strikes/index.html.

2 Savino et al. v. Hodgeson, No. 1:20-CV-10617 (D. Mass. March 27, 2020) http://lawyersforcivilrights.org/wp-content/uploads/2020/03/Complaint-AS-FILED-Savino-v.-

Hodgson.pdf; Id. at 7 II 28. The plaintiffs alleged that the only adequate remedy was release of vulnerable detainees so that they could practice safety protocols outside of the jail. Id. at 8 II 31 .

$3 \quad$ Id. at 15 II $68 ;$ id. at 17 प 78.

4 Shannon Dooling, ICE Detainees Allege Assault, Isolation Used as Retaliation at Bristol County; Sheriff Denies Claims, WBUR News (May 6, 2020), https://www.wbur.org/news/2020/05/06/ bristol-sheriff-hodgson-altercation-recording.

5 Shannon Dooling, 47 ICE Detainees Released from Bristol County: Judge Wants Virus Test Reporting for Those Still Held, WBUR NEws (Apr. 26, 2020), https://www.wbur.org/news/2020/04/24 /47-ice-detainees-released-from-bristol-county-judge-wants-reports-on-testing-among-thoseremaining.

6 Shoichet, supra note 1.

7 Shannon Dooling, ICE Detainees Hospitalized, Sheriff Reports 'Extensive Damage' after Coronavirus-Based Incident in Bristol County Jail, WBUR News (May 2, 2020), https://www.wbur. org/news/2020/05/01/coronavirus-ice-detainees-massachusetts-detention. 
detainees with dogs and pepper spray. ${ }^{8}$ Amid the melee, a detainee wrote "Help Us" in soap on the window. ${ }^{9}$ Bristol County detainees were not alone. In response to the pandemic, protests and hunger strikes occurred as a last resort in other jails and prisons. ${ }^{10}$

Riots, hunger strikes, and writing on windows demonstrate a larger problem: the failure of basic channels of communication and complaint to produce change inside America's jails and prisons. When grievances to prison officials, complaints to courts, and public requests for assistance fail, protest follows. In this essay, I trace the roots of the protests back to the exclusion of incarcerated people from public discourse, highlighting how prisons and jails function as overly authoritarian institutions that skew public discourse about incarceration and public safety. By the phrase 'authoritarian institution,' I mean to convey several aspects of jails and prisons. People living in prisons and jails are restricted in their political engagement while being placed in circumstances in which they are totally dependent on the prison administration to meet basic needs. ${ }^{11}$ Prisons and jails, like other authoritarian institutions, often block, discourage, discredit, and retaliate against organized, political speech. ${ }^{12}$ At the same time, the vulnerability of incarcerated people-born of total dependence on the institution-makes their speech essential to ensuring their safety. ${ }^{13}$ The residents of authoritarian institutions are thus at the mercy of the institution, a problem compounded by the lack of transparency that free speech and robust means of asserting legal rights can provide to expose government misconduct. ${ }^{14}$

$8 \quad I d$.

$9 \quad I d$.

10 Keri Blakinger, Coronavirus Restrictions Stoke Tensions in Lock-ups Across U.S., THE Marshall Project (Apr. 2, 2020, 6:00 AM), https://www.themarshallproject.org/2020/04/02/ coronavirus-restrictions-stoke-tensions-in-lock-ups-across-u-s (describing protests in prisons in response to inadequate safety protocols, lockdowns, and inattentive medical care for sick prisoners).

11 Erwin Chemerinsky, The Constitution in Authoritarian Institutions, 32 SuFf. L. REv. 441 (1999) (critiquing unwarranted judicial deference to authoritarian institutions like prisons, military, and schools); ERving Goffman, Asylums: Essays on the Social Situation of Mental Patients and OTHER INMATES 7 (1961) [hereinafter ASYLUMS] (defining “total institutions).

12 See Andrea Armstrong, Racial Origins of Doctrines Limiting Prisoner Protest Speech, 60 How. L. J. 221, 226-29, 259 (2016) [hereinafter Racial Origins] (discussing the prevalence of and judicial deference to prison regulations that burden speech activities).

13 Chemerinsky, supra note 11, at 458 (urging less deferential judicial review of authoritarian institutions because of the likelihood of "serious abuses of power and violations of rights" and because "the political process is extremely unlikely to provide any protections in these arenas").

14 Angela Y. Davis has noted, for example, that U.S. prisons have similarities with the extraterritorial "black sites" of the U.S. War on Terror in that they are spaces of government control beyond the reach of political or legal accountability. ANGELA Y. DAVIS, ABOLITION DEMOCRACY 88, 110 (2005) (arguing that Abu Ghraib and Guantanamo degrade democracy because they establish legal black holes that lack transparency and power checks, and that "[y]ou could say the same think about domestic 
Despite these challenges, prison and jail protests have increased over the past ten to fifteen years, as can be seen in the 2013 hunger strike organized at California's Pelican Bay State Prison that led 30,000 incarcerated people in California to refuse food, ${ }^{15}$ and the national prison strikes of 2016 and 2018. ${ }^{16}$ On the heels of these protests, the COVID-19 pandemic caused incarcerated activism to surge, with over 119 documented instances of incarcerated protests and strikes during the first ninety days of the pandemic. ${ }^{17}$

Prisoners' pandemic protests have occurred despite formidable barriers to their participation. Some of the barriers to prisoner speech are physical and legal, as discussed in Part I of this essay. The pandemic has heightened these barriers through lockdowns, moratoria on visits, and restricted access to telephones and computers. These heightened, pandemic restrictions might largely pass constitutional muster under the Supreme Court's deferential standards for reviewing prison restrictions on speech and assembly. ${ }^{18}$ Yet, despite their presumed legality under governing precedent, the restrictions on communication seem both wrong and dangerous during a pandemic, limiting what the public knows about COVID-19 in prisons and jails.

The barriers to and need for communication from incarcerated people can best be understood within the framework of a political philosophy called epistemic injustice theory, which I describe in more detail in Part I of this essay. Epistemic injustice occurs when a socially disfavored group is unable to contribute knowledge to public discussions. ${ }^{19}$ The group may be denied channels of communication, disbelieved when they speak, or simply deemed unintelligible. ${ }^{20}$

prisons").

15 How 4 Inmates Launched a Statewide Hunger Strike from Solitary, NAT'L PUB. RADIO (Mar. 4, 2014, 11:00 AM), https://www.npr.org/2014/03/06/286794055/how-four-inmates-launched-astatewide-hunger-strike-from-solitary (describing origin of state-wide hunger strike of prisoners protesting solitary confinement and other prison practices).

16 For reporting on prison protests that have occurred since 2010, see the online journal, PERILOUS CHRON., which "track[s] information on prison uprisings, riots, protests, strikes and other disturbances ... in U.S. and Canada" with a combination of their own reporting, news outlets, and "crowdsourced information." https://perilouschronicle.com/about/.

17 First 90 Days of Prisoner Resistance to COVID-19: Report on Events, Data, and Trends, PERILOus CHRON. (Nov. 12, 2020), https://perilouschronicle.com/2020/11/12/COVID-prisonerresistance-first-90-days-full-report/ (comparing 119 acts of resistance in prisons during the first 90 days of COVID-19 to the 83 acts of prison resistance in 2018, and 53 in 2016).

18 Discussed infra Part II. For a discussion of the role of judicial deference in solidifying the power of prisons as authoritarian institutions, see Chemerinsky, supra note 11, at 450-55; Sharon Dolovich, Forms of Deference in Prison Law, 24 FED. SENT'G REP. 245, 245 (2012).

19 MirANDA Fricker, EPISTEMIC INJUSTICE 4-5 (2007).

20 In another article, I argue that epistemic injustice explains why incarcerated accounts of prisons' cruelties are deemed irrelevant to sentencing policy and practice, and why prisoner voices are essential to correcting sentencing errors that are otherwise based on a thin concept of the punishment 
Although incarcerated people are silenced and discredited, their increased activism is cause for hope. While speaking does not always produce change, the accumulation of grievances may eventually counter an official narrative that casts grievances as idiosyncratic or not trustworthy. One or two complaints may be ignored, but an aggregate of similar complaints eventually paints a picture of a systemic problem. In civil rights suits brought by incarcerated people, for example, we can see how aggregated first-person accounts of harm contained in supporting declarations help establish the factual predicate for finding a violation of legal rights. ${ }^{21}$ The declarations demonstrate how first-person accounts can influence political thinking about what is unjust. To borrow from Judith Shklar's theory of injustice, first person accounts of harm are useful in the political determination of what is bad luck and what is injustice. ${ }^{22}$

The organized presentation of grievances is necessary not just in lawsuits, but also in the political sphere. Legal and political challenges are often complementary. The establishment of rights through legal action can serve to "initiate and nurture political mobilization." 23 But political change sometimes moves more quickly and produces results unavailable under the narrower categories of legal relief. Moreover, it is precisely the political sphere that is damaged by silencing prisoners. Political talking and organizing are hallmarks of democracy. ${ }^{24} \mathrm{We}$ talk before and after voting so that everyone understands the options and impact of the vote. ${ }^{25}$ While prisons are not democratic institutions by design or practice, they are governmental entities within a democracy. Discussions about how to address COVID-19 risks in jails and prisons play out in the media, state houses, city councils, and streets as well as in courts. ${ }^{26}$ The public discussion of sentencing and prison policies is distorted through exclusion of the perspectives of incarcerated people, removing an important check on the near-absolute power of prison and jail administrations. ${ }^{27}$ When we

of imprisonment. M. Eve Hanan, Invisible Prisons, 54 U.C. DAvIS. L. REV. 1185 (2020).

21 Discussed infra Part I.A.

22 Judith N. SHKLAR, THE FACES OF INJUSTICE 19 (1988) (“Most injustices occur continuously within the framework of an established polity with an operative system of law, in normal times"); Medina, The Epistemology of Resistance 13 (2013) [hereinafter Epistemology] (citing Id. at 17) ("This normal model of justice does not ignore injustice but it does tend to reduce it to a prelude to or a rejection and breakdown of justice, as if injustice were a surprising abnormality.").

23 James B. Jacobs, The Prisoners' Rights Movement and Its Impacts, 1960-1980, 2 CRIME \& Just. 429, 442 (1980), quoting Stuart A. Scheingold, The Politics of Rights 131 (1974).

24 Medina, EPistemology, supra note 22, at 5 ("Democracy is not only about voting but also about talking").

25 Id. (noting that, "without such discussion, voting would give expression only to private preferences and not to a public interest").

26 Discussed infra Part II.

27 Andrea C. Armstrong, No Prisoner Left Behind: Enhancing Public Transparency of Penal Institutions, 25 STAN. L. \& POL'y REV. 435, 458 (2014) [hereinafter No Prisoner] (arguing that accurate 
contemplate "what version of democracy to which we are asked to consent," we should do so with full awareness and participation of the 2.3 million people living in its prisons and jails. ${ }^{28}$

In Part I, I describe and apply the theory of epistemic injustice to prisoner speech and offer some examples of heightened challenges to communication that occurred during the pandemic. I discuss how the deferential legal standard for reviewing curtailment of speech and association rights in prison has left prisoners with no sure means of conveying emergencies to the outside world. COVID-19 highlights the danger of the deferential standard. In Part II, I discuss the epistemic and political efforts of incarcerated people to be heard during the pandemic within the historical context of prisoner activism and silencing. In Part III, I discuss incarcerated activism within the context of the benefits of speech to democracy and the dangers of authoritarianism.

\section{SANCTIONED SILENCING}

"Our social distancing took effect with the jury's verdict."29

Barriers to communication for incarcerated people can be thought of as a type of epistemic injustice. Epistemic injustice theory critiques socio-political arrangements that exclude disfavored social groups from contributing information that is important public conversations. ${ }^{30}$ As a result of epistemic injustice, people from disfavored social groups are unable to influence policies or public opinion. In another Article, I discuss the impact of epistemic injustice against incarcerated people on sentencing policy and practice. ${ }^{31}$ Here, I briefly sketch the aspects or epistemic injustice that are relevant to understanding the importance of incarcerated voices to addressing the COVID-19 crisis in prisons and jails.

To be sure, it is debatable whether prisoners, jail detainees, and immigration detainees can be thought of as a cohesive social group. Not all have been convicted of crimes, and immigration detainees may not have been formally accused of any crime. Yet, by virtue of having been institutionalized in a jail or prison, incarcerated people share a similar stigma as a disfavored social group. Through a variety of means, the government has deemed them unfit for release into society. As a result, one can expect that the larger society will value their knowledge and perspectives less than a person who has not been incarcerated.

information about what is happening in prisons and jails is essential to an informed electorate).

28 DAVIS, supra note 14 , at 43.

29 Derek Trumbo, Temperature Check, PEN AMERICA (Apr. 1, 2020), https://pen.org/ temperature-check-1/\#dispatch (incarcerated dramatist reflects on pandemic in prison).

30 See FRICKER, supra note 19, at 1-2.

31 M. Eve Hanan, Invisible Prisons, 54 U.C. DAvIS L. REV. 1185 (2020). 
The high rates of incarceration of Black men and women result in an overlapping epistemic injustice that is rooted in white supremacy. As the predecessors to modern epistemic injustice theory have pointed out, the observations and perspectives Black people and other oppressed groups are often "discredited, or simply absorbed and marginalized in existing paradigms." 32 White supremacy as an ideology creates an epistemic framework that discredits the claims of Black people and elevates the claims of white people. ${ }^{33}$ In sum, then, due to overlapping stigmas, the views of incarcerated people in general and Black prisoners and detainees in particular may be met with both disbelief and total disinterest for reasons unrelated to the merits of their claims.

At least three types of epistemic injustice are relevant to analyzing the exclusion of prisoners' voices. First are the physical and legal barriers to political participation. Living behind prison walls with restricted outside contacts, incarcerated people simply have fewer means of communication. The precarious nature of prisoners' access to modes of communication became strikingly clear during the pandemic, when lockdowns and moratoria on social visits became the norm. Moreover, as I discuss in the next section, rules that restrict prisoner communication for administrative purposes are difficult to challenge precisely because the prison and the courts are unable to see the epistemic necessity of incarcerated speech.

Second, epistemic injustice occurs when the speech of a stigmatized grouplike incarcerated people - is discredited because members of the stigmatized group are not viewed as trusted speakers. ${ }^{34}$ Incarcerated people have what sociologist Erving Goffman calls "spoiled identities" that discredit them as speakers and render their claims less pressing than those of groups with unspoiled identities. ${ }^{35}$ It is assumed that members of disfavored groups lie, exaggerate, and distort the truth for personal gain.

Third, and related closely to the second point, incarcerated people may be so thoroughly stigmatized that information is not solicited from them in the first place. ${ }^{36}$

32 Patricia Hill Collins, Black Feminist Thought 269, 301 (1990) (discussing Black feminist perspectives as "subjugated knowledge"). Epistemic injustice theory can be thought of as part of an intellectual lineage that examines the intersection of epistemology and subordination. See, e.g., Nancy Tuana, Feminist Epistemology, The Routledge HandBooK of Epistemic Injustice 125-27 (discussing how epistemic injustice theory developed from feminist and anti-colonial philosophies).

33 Charles W. Mills, Ideology, The Routledge Handbook of Epistemic Injustice, supra note 32 , at 100,105 .

34 Hanan, supra note 20, at 1217, citing FRICKER, supra note 19, at 23 (explaining that testimonial injustice occurs when the speaker is not credited because of a stereotype about "people like" the speaker).

35 Erving Goffman, Stigma: Notes of the Management of Spoiled Identity 71 (1963) [hereinafter STIGMA] (describing how the public image of the stigmatized person eclipses individual characteristics).

36 Hanan, supra note 20, at 1219, citing FRICKER, supra note 19, at 147-48 (describing process through which disfavored groups are excluded from contributing to public discussions). 
A preemptive rejection of the stigmatized group's ability to provide information is often manifest in the breach: the failure to inquire about what incarcerated people have to say about prison conditions during COVID-19. Rather than discrediting a particular claim made by prisoners, preemptive rejection rests on seeing the disfavored group as so unintelligible - exotic, dangerous, and unlike normal people - as to require their exclusion from public discourse.

An example of these three types of epistemic injustice against incarcerated people can be seen in Heather Ann Thompson's historical account of the 1971 Attica Correctional Facility uprising and its aftermath. ${ }^{37}$ When state troopers stormed the prison to regain control after the prisoner uprising, the troopers shot prisoners and hostages alike. ${ }^{38}$ Those outside the prison, including the journalists, the public, and state officials, were unable to observe what was happening inside the prison during the retaking. ${ }^{39}$ As a result, state authorities were able to advance a distorted view of the retaking that was designed to protect the state from censure and lawsuits. ${ }^{40}$ Prisoners were blamed for deaths of hostages and fellow prisoners even though most deaths were the result of gunshots, and only the troopers had access to guns. ${ }^{41}$ Moreover, the epistemic injustice deployed against Attica prisoners relied on antiBlack prejudice. From the day that troopers stormed Attica, authorities portrayed the prisoners as Black radicals to shore up support for the deaths, injuries, and terror that the troopers inflicted on the prison population. ${ }^{42}$

Some of the men incarcerated at Attica were eventually interviewed, anddecades later — others testified in civil suits against the prison administration. ${ }^{43}$ But, until recently, their claims were discounted in favor of the official account of prisoner violence. ${ }^{44}$ The epistemic injustice produced long-term political consequences. Thompson suggests that the skewed narrative of prisoner violence,

37 Heather Ann Thompson, Blood on the Water: The Attica Prison Uprising of 1971 AND ITS LEGACY 266-68 (2016).

38 Id. at 180-92 (describing the troopers' actions while retaking the prison).

39 Id. at 190 ("observers and state officials had no real idea what was happening in [the prison].").

$40 \quad$ Id. at $266-68$.

41 Id. at 194-95 (describing how officials falsely claimed that incarcerated men mutilated, disemboweled, and castrated hostages with knives).

42 Id. at 200 (quoting Governor Rockefeller telling President Nixon that " $\mathrm{t}]$ he whole thing was led by the blacks"'); id. at 562 .

43 Men incarcerated at Attica and their attorneys spent thirty years attempting to convey to the public the brutality that they experienced during the retaking of the prison and the retaliation that they experienced because of their involvement in the uprising. Id. at 503-04.

44 Id. at 196 (describing how "[t]he inflammatory stories of prisoner depravity reported by New York state officials found their way onto the front pages of the nation's more highly regarded newspapers."). 
combined with the suppression of the prisoners' stories of state torture and killings, may have "helped to fuel [] a historically unprecedented backlash against all efforts to humanize prison conditions in America" in the decades that followed. ${ }^{45}$ This pattern of recasting prisoner activism as a pure security threat requiring forceful suppression reflects all three types of epistemic injustice addressed in this essay: (1) institutional barriers to communication; (2) the discrediting of statements made by incarcerated people; and (3) the rejection of incarcerated people as a group capable of generating information important to the public.

In the remainder of this Part, I describe these three aspects of epistemic injustice in carceral settings in general and during the pandemic. Where relevant, I note legal standards that permit severe curtailment of communication and association so long as the restrictions are reasonably related to a legitimate penal interest.

\section{A. Speech Barriers}

Incarcerated people's participation in political speech involves at least three channels: (1) incoming information; (2) outgoing information; and (3) communication among incarcerated people, particularly in the form of organizing to address grievances. ${ }^{46}$ All three types of communication have been restricted during the pandemic, restrictions that would be difficult to challenge under the Court's existing deferential standards ${ }^{47}$ While not addressing the legal merits, I refer to the Court's standards for determining whether a regulation restricting speech and assembly violates the First Amendment in order to highlight the fragility of public participation by incarcerated people.

The current test to determine whether a prison regulation burdens an incarcerated person's First Amendment rights was articulated in Turner v. Safley, where two regulations were challenged. ${ }^{48}$ One regulation limited communication among prisoners and the second restricted prisoners from marrying without a compelling reason and without permission from the prison's "treatment team." ${ }^{49}$ Jettisoning prior language that prison regulations that impinge on constitutional rights must be the least restrictive alternative to serve a legitimate penological interest, the Turner Court set forth four factors for courts to consider: (1) the

45 Id. at 561 .

46 My taxonomy derives from, but is not identical to, the taxonomy laid out by Evan Bianchi \& David Shapiro, Locked Up, Shut Up: Why Speech in Prison Matters, 92 ST. John's L. Rev. 1, 4 (2018) (categorizing prison speech into four categories: (1) outside in; (2) inside out; (3) dialogue between inside and outside; and (4) among incarcerated people).

47 See Racial Origins, supra note 12, 236-61 (analyzing Supreme Court cases upholding the constitutionality of various regulations restricting the speech rights of incarcerated people).

48 Turner v. Safley, 482 U.S. 78, 89 (1987). Some circuits apply the more exacting test articulated in Procunier v. Martinez. 416 U.S. 396, 413 (1974), discussed infra Part II.A.2.

49 Turner, 482 U.S. at 81-82. 
existence of "a valid rational connection" between the regulation and the government interest; (2) the existence of alternative means of exercising the constitutional right; (3) consideration of how accommodating the right will impact the prison; and (4) the "absence of ready alternatives." ${ }^{50}$ The Court held that the restriction on prisoner communication with other prisoners was valid primarily because it was reasonably related to the legitimate penological interest of preventing prisoners from planning escapes and other bad acts, but that the regulation on marriage was overbroad and thus did not-as written - survive constitutional scrutiny. ${ }^{51}$

In applying the Turner test, courts have demonstrated a deferential attitude toward prison officials. ${ }^{52}$ In 2003, for example, the Supreme Court upheld a prison policy that dramatically limited visits, including visits by the children of incarcerated parents. ${ }^{53}$ The Court applied all four prongs of the Turner test, noting that the regulations did not prevent prisoners from communicating with outsiders through letters and telephone calls; that the impact of accommodating the requested visits would be either too expensive or would compromise safety; and that the plaintiff prisoners did not present alternatives to the regulation that would undermine the reasonableness of the regulations.$^{54}$ Critically, the Court held that the restrictions on visits were reasonably related to the legitimate penological interests of protecting children and improving prison security by reducing the overall number of visitors. ${ }^{55}$

Over time the existence of a rational connection between the regulation and a legitimate penological interest "has emerged as the crux of the standard." ${ }^{56}$ Indeed, the phrase "legitimate penological interests" appears to be a catchall for anything having to do with safety, orderliness, and the penological goals of retribution, rehabilitation, deterrence and incapacitation. ${ }^{57}$ Because almost anything could be reasonably related to "legitimate penal interests," prisons have almost complete discretion to curtail communication. ${ }^{58}$

$50 \quad$ Id. at $89-90$.

$51 \quad$ Id. at 81 .

52 Sharon Dolovich, Forms of Deference in Prison Law, 24 FED. SENT'G REP. 245, 245 (2012).

53 Overton v. Bazzetta, 539 U.S. 126, 133 (2003).

54 Id. at $135-36$.

55 Id. at $133-34$.

56 Margot Schlager et al., Incarceration and the Law, Cases and Materials 366 (2020).

57 See, e.g., O’Lone v. Estate of Shabazz, 482 U.S. 342, 348 (describing deterrence, rehabilitation and institutional safety as "valid penological objectives" that might limit the incarcerated person's "exercise of constitutional rights").

58 Prisoners are granted greater protection for religious practices under the Protection of Religious Exercise of Institutionalized Persons Act, 42 U.S.C. $\S \S 2000 c c-2000 c c-5$. 
As a general matter, the Court's deference to carceral restrictions of speech is anchored to the idea that "freedom of association is among the rights least compatible with incarceration. ${ }^{" 59}$ But a paradox results: Restrictions on incarcerated activism may seem to be related to legitimate penological interests because advocating to change the status quo is disruptive. Disruption, even in the form of self-advocacy, will appear to endanger security. As such, any restrictions on organized speech will appear to be reasonably related to legitimate penal interests. Yet, at the same time, incarcerated activism may be essential to alerting the outside world about intolerable conditions within the prison.

Although, the ability to communicate with the outside world varies by facility and by security protocols that attach to the prisoner's classification of risk, some generalization is possible. Total separation from the outside world is a defining characteristic of carceral facilities. Prison is split into two populations: incarcerated people and staff. ${ }^{60}$ By design, incarcerated people have extremely limited contact with the outside world, while staff return to the outside world after their shift each day. ${ }^{61}$ As one incarcerated man explains:

I don't have a computer; no access to the internet, no way to run an online search. My ability to reach outside prison - in the minimal, monitored and restricted ways I'm permitted - is limited by how much money I have, or don't have, in my prison account. Phone calls cost me more than they cost an unincarcerated person. And I don't have access to a phone directory. Letters also cost me more to mail than they cost an unincarcerated person. And the pennies I make per house from my prison job provide me barely enough for soap, deodorant, and toothpaste. ${ }^{62}$

Simply put, communication is difficult by design.

\section{Communication from Outside to Incarcerated People}

Communication from the outside world includes access to media and books as well as the type of information that is gleaned from letters, emails, and conversations during visits and phone calls. As I discuss more in the following section on outgoing communication, with the exception of privileged legal communications, prisons have the authority to restrict visits and phone calls, and to read and sometimes censor

59 Overton, 539 U.S. at 131.

60 The term "total institution" appears to have been coined by Erving Goffman in his sociological study of the commonalities among various institutions. GOFFMAN, supra note 11, at 7.

61 GofFMAN, supra note 11 , at 7.

62 Arthur Longworth, Why It is So Hard to Write from Prison, Crosscut (Apr. 23, 2019), https://crosscut.com/2019/04/why-its-so-hard-write-prison. 
or reject general mail. ${ }^{63}$

With regard to incoming media sources, prisons and jails offer limited access to books and digital media. Many prisons have anemic book holdings, offering only what is minimally required to meet the standard of having a law library ${ }^{64}$ And, given the regularity with which we scroll through applications on our phones for information and perspectives posted on social media and through news outlets, it is striking that prisoners have such limited access to the internet. Prisons can severely curtail access to written publications so long as the prison states that denying incarcerated people the ability to read is related to a "legitimate penological interest." ${ }^{\prime 5}$ Prisons may categorically reject all books sent by family and friends for security reasons. ${ }^{66}$ While a publication generally may not be rejected "solely because its content is religious, philosophical, political, social or sexual, or because its content is unpopular or repugnant, ${ }^{, 67}$ prisons may reject incoming publications that they deem "detrimental to institutional security" based on content. ${ }^{68}$

These practical and rule-based limitations harm prisoner participation in public discussions. Absorbing a breadth of information from the outside world helps one adequately evaluate one's circumstances, formulate grievances, and identify channels of redress. Inability to read about political movements, for example, hobbles one's ability to strategize how to communicate politically. ${ }^{69}$ Writing in dissent in a case upholding prison restrictions on incoming media, Justice Stevens illustrated his criticism of the application of the "legitimate penological interests" standard by referring to a news article that prison officials rejected.$^{70}$ The article described a prisoner who died after receiving poor medical care during an asthma attack. ${ }^{71}$ The story clearly would be of interest to prisoners concerned about their well-being in prison. Indeed, the very reason for the prison rejecting dissemination

63 Wolff v. McDonnell, 418 U.S. 539, 539 (1974) (open mail in prisoner's presence to check for contraband but content of letter not read).

64 See discussion of prisoner litigation, infra Part II.A.4.

65 Beard v. Banks, 548 U.S. 521 (2006) (no constitutional violation where prison barred some inmates from all print material except for legal and religious publications).

66 Bell v. Wolfish, 441 U.S. 520, 562 (1979) (deferring to prison officials security expertise to decide whether to permit prisoners to receive books mailed from private citizens rather than directly from publishers).

$67 \quad$ See, e.g., 28 C.F.R. $\$ \S 540.70,540.71$.

68 Thornburg v. Abbott, 490 U.S. 401, 403, 415 (1989).

69 Bianchi \& Shapiro, supra note 46, at 4 (noting how "the breadth of ideas and information that prisoners can receive-from those outside prison walls and from other prisoners - ultimately affects their ability to produce outwardly-directed speech").

70 Thornburg, supra note 68, 490 U.S. at 420 (Stevens, J. concurring in part and dissenting in part).

$71 \quad I d$. 
of the story is the reason the story is important for prisoner self-advocacy: addressing medical care failures in treating sick prisoners.

The pandemic highlights the urgency of access to current and accurate information in order for incarcerated people to make decisions about how to advocate for themselves in the face of a mortal threat. Some incarcerated people reported that they received inadequate information about the pandemic and its safety protocols due to limited print and digital media access. ${ }^{72}$ Without understanding coronavirus transmission and dangers, incarcerated people were unable to formulate demands to protect their safety.

\section{Incarcerated People Speaking to the Outside World}

What prisoners write or say to people outside prison is similarly limited due to practical barriers, surveillance, and censorship. Prisons may severely curtail the prisoner's contact - through visits or otherwise - with family and friends. ${ }^{73}$ Even when permitted, visits can only occur at certain times and only if family and friends have time, money, and transportation to get to the prison. Incarcerated people may be denied social visits either as a punishment or as an administrative policy. ${ }^{74}$ Indeed, prisoners in segregation or in high-security facilities have difficulty communicating with other prisoners and almost no communication with the outside world. ${ }^{75}$

The pandemic brought new restrictions. All states suspended family visits in March and April of 2020. ${ }^{76}$ The Marshall Project reported that twelve states suspended all prison visits and twenty-nine states allowed only legal visits. ${ }^{77}$ Classes

72 See, e.g., Christopher Blackwell, What Coronavirus Quarantine Looks Like in Prison, THE MARShall Project (Mar. 21, 2020), https://www.themarshallproject.org/2020/03/1 8/whatcoronavirus-quarantine-looks-like-in-prison ("As the virus continued to spread in the outside world, I along with many others inside waiting for instructions on what we would do ....").

73 See, e.g., Overton, 539 U.S. 126 (2003); Block v. Rutherford, 468 U.S. 576 (1984) (upholding restrictions on visits for pretrial detainees as reasonably related to penal interests). Legal visits are an exception. While unfettered access is not required, prisons and jails must permit reasonable access to attorneys and paralegals. See Procunier v. Martinez, 416 U.S. 396, 419 (1974), overruled on other grounds by Thornburgh v. Abbott, 490 U.S. 401 (1989).

74 See, e.g., Overton, 539 U.S. 126 (2003).

75 Giovanna Shay, Ad Law Incarcerated, 14 BERKELEY J. CRIM. L. 329, 337-38 (2009) (discussing how technologies like the "super max" reduce contact among prisoners and between prisoners and guards through automation); Mikel-Meredith Weidman, The Culture of Judicial Deference and the Problem of Supermax Prisons, 51 UCLA L. REV. 1505, 1526 ("the typical supermax minimizes sensory stimulation and human contact").

76 Joseph Neff, North Carolina Prisoners Still Working in Chicken Plants, Despite Coronavirus Fears, The MARshall Project (Mar. 19, 2020), https://www.themarshallproject.org/2020/03/19/ north-carolina-prisoners-still-working-in-chicken-plants-despite-coronavirus-fears.

77 How Prisons in Each State Are Restricting Visits Due to Coronavirus, The Marshall PROJECT (Nov. 25, 2020), https://www.themarshallproject.org/2020/03/17/tracking-prisons-response- 
and meetings that relied on outside volunteers also were suspended. ${ }^{78}$ With regard to telephone access, even under normal circumstances, phone calls can be restricted..$^{79}$ When permitted, they are so prohibitively expensive that family and friends may be unable to accept the cost associated with the call. ${ }^{80}$ As a result, phone calls will be brief and infrequent. ${ }^{81}$ During the pandemic, incarcerated people who had access to shared telephones sometimes avoided making calls because of hygiene concerns.$^{82}$ COVID-19 related suspension of calls, social visits, and programs not only harmed the mental health of incarcerated people. ${ }^{83}$ It also blocked a channel for incarcerated people to communicate with the outside world about unsafe prison conditions. ${ }^{84}$

Cell phones are banned in most prisons, and possession of a cell phone by an incarcerated person is a crime in some states. ${ }^{85}$ While the restriction on cell phones may make sense for security reasons, the prohibition dramatically impacts

to-coronavirus.

78 See, e.g., Trumbo, supra note 29 (describing the suspension of "all visits, religious services, programs and distractions" because of the pandemic).

79 See, e.g., Aswegan v. Henry, 981 F.2d 313, 314 (8th Cir. 1992) ("Although prisoners have a constitutional right of meaningful access to the courts, prisoners do not have a right to any particular means of access, including unlimited telephone use," citing Bounds v. Smith, 430 U.S. 817, 823, 832 (1977)).

80 Phone companies providing telephone services to jails and prisons charge exorbitant prices, a practice recently the source of a class action antitrust lawsuit in Maryland. Albert et al. v. Global Tel*Link Corp et al., 8:20-CV-1936 II 1 (U.S. Dist. MD 2020) (alleging that defendant telephone companies set an "astronomical," fixed price for telephone calls placed from prison). See also Giovanna Shay, Ad Law Incarcerated, 14 BERKELEY J. CRIM. L. 329, 357 (2009).

81 During the pandemic, many prisoners had even less access to telephones. A prison in Santa Barbara forbade not only all visits, but also all phone calls. Corrected Compl. Class Action For Decl. and Inj. Relief and Pet. For Writ of Habeas Corpus at 41, Torres et al. v. Milusnic et al., No. 2:20-CV04450 (C.D. Cal May 1, 2020), https://clearinghouse.net/chDocs/public/PC-CA-0079-0010.pdf.

82 See, e.g., Christopher Blackwell, What Coronavirus Quarantine Looks Like in Prison, THE MARShall Project (Mar. 18, 2020), https://www.themarshallproject.org/2020/03/18/ whatcoronavirus-quarantine-looks-like-in-prison (prisoners told to put a sock over the receiver to protect against fomite transmission of coronavirus).

83 Oscar Brown in Norm Conti ET AL., EDS. Life Sentences: Writings From Inside An AMERICAN PRISON 119 (2019) ("One of the most important aspects of mental stability in prison is the visit.").

84 Keri Blakinger, Coronavirus Restrictions Stoke Tensions in Lock-ups Across U.S., THE MARShALl PROJECT (Apr. 2, 2020), https://www.themarshallproject.org/2020/04/02/corona virusrestrictions-stoke-tensions-in-lock-ups-across-u-s (describing curtailment of educational programs in prisons during the pandemic).

85 See, e.g., Cal. Penal Code $\$ 4576$ (West 2019) (California statute criminalizing cell phone possession in prison). 
communication with the outside world ${ }^{86}$ Consider how important internet dissemination of police shootings has been to the Movement for Black Lives. Without cell phones and with only limited, supervised access to the internet, prisoners cannot record and disseminate abuse, brutality, or unsanitary conditions. ${ }^{87}$ As described elsewhere in this essay, prisoners can and do document prison conditions on contraband cell phones, but they do so at great personal risk.

General mail may be the only aspect of prison communication that remained largely unchanged during the pandemic. Mailing a letter, however, presents physical challenges. It requires paper, envelopes, pen, and stamps. Electronic communication also is limited. Generally barred from unsupervised internet use and social media usage, incarcerated people have access to supervised, text-only email accounts if they have any access at all. ${ }^{88}$

Nonprivileged, general mail is routinely inspected. ${ }^{89}$ The standard of review for outgoing speech from prison varies by circuit, with some circuits applying the Turner standard and others the standard laid out in Procunier v. Martinez. ${ }^{90}$ In Martinez, the Court held that a rule censoring outgoing mail must "further an important or substantial governmental interest unrelated to the suppression of expression," and be "no greater than is necessary or essential to the protection of the particular governmental interest involved."

86 This is not to say that prisoners have no contraband cell phones. By some reports, cell phone use is common and subject to an ongoing "cat and mouse game" of seizures. Kevin Rouse \& Pendarvis Harshaw, Inside the Prison System 's Illicit Digital World, SPLINTER (Feb. 3, 2015), https://splinternews. com/inside-the-prison-systems-illicit-digital-world-1793844988.

87 Ben Branstetter, The Case for Internet Access in Prisons, Washington Post Op-Ed (Feb. 9, 2015) (arguing that internet access for prisoners is essential to uncovering abuse by guards and that, by "blocking convicts from even a censored version of the digital world, we're denying them not just the ability to survive in a culture that has grown without them but also the ability to contend with life in prison.").

88 Most federal prisoners have some, limited access to text-only emailing through Trust Fund Limited Computer System. TRULING Topics, FED. BureaU OF PRISONS, https://www.bop. gov/inmates/trulincs.jsp (last visited Oct. 2, 2020).

89 Wolff v. McDonnell, 418 U.S. 539, 575 (1974) (open mail in prisoner's presence to check for contraband but content of letter not read).

90 Procunier v. Martinez, 416 U.S. 396 (1974) (prison regulation survives constitutional challenge if it (1) serves an "important or substantial governmental interest unrelated to the suppression of expression" and (2) is "no greater than is necessary or essential to the protection of the particular governmental interest"). Id. at 404-414 (1974) (prisons may not censor letters because they "unduly complain" or "magnify grievances" about prison). See also Bianchi \& Shapiro, supra note 46, 10-12 (explaining that circuits are split regarding whether the Supreme Court's decision in Thornburgh $v$. Abbott, 490 U.S. 401, 407-08 (1989), which applied the more deferential standard in Turner, overruled Martinez for outgoing mail, too).

91 Procunier, 416 U.S. at 413. 
on the prison than the Turner standard..$^{92}$ Regardless of the standard applied, incarcerated people may have the same concern: whether their outgoing letters will be read by the very staff members whom they complain of in their letters. An incarcerated person may mute their criticism because they anticipate surveillance that will lead to retaliation. ${ }^{93}$

Particularly detrimental to prisoners' ability to tell the outside world about life in prison are limitations on prisoners' ability to speak to the press. Prisons may forbid the press from interviewing prisoners so long as the decision is based on security concerns. ${ }^{94}$ With regard to letters, some circuits consider letters written to the press privileged communication, while others treat letters to the press like letters to family and friends that may be surveilled and censored. ${ }^{95}$ Some state regulations, permit the prison to open letters to the press. ${ }^{96}$ If the prison opens letters to the press, the incarcerated person reporting abuse at the hands of a guard, for example, runs the risk of having the same guard read her letter to the local newspaper. ${ }^{97}$

In arguing for more stringent legal protection of the right of incarcerated people to speak to the public, Demetria Frank notes how "perplexing" it is that any group of American citizens would need to engage in a hunger strike on U.S. soil in order to be heard." ${ }^{98}$ The pandemic highlights this perplexity. The barriers to communication between incarcerated people and the outside intensified dramatically, leading to protests and hunger strikes when the ordinary channels of grievance were ineffective. ${ }^{99}$ And, it is likely that the reduced ability of incarcerated

92 Bianchi \& Shapiro, supra note 46, at 11.

93 Medina notes fear of retaliation among jail detainees. José Medina, Agential Epistemic Injustice and Collective Epistemic Resistance in the Criminal Justice System [hereinafter Epistemic Agential Injustice] 11 (forthcoming 2021).

94 The Court again stressed that judicial deference is necessary because security is "peculiarly within the province and professional expertise of corrections officials." Pell v. Procunier, 417 U.S. 817, 827 (1974).

95 Dennis Temko, Prisoners and the Press: The First Amendment Antidote to Civil Death After PLRA, 49 CAL. W. L. REv. 195, 205-07 (2013) (comparing Fifth and Seventh Circuits treatment of letters from prisoners to the press).

96 Id. at 213-16 (fourteen of thirty-two states responding to the survey reported that prison officials may open letters to press).

97 See id. at 212 ("The same guards who were engaged in the abuse would likely have been the readers of inmates' outgoing mail.”).

98 Demetria D. Frank, Prisoner-to-Public Communication, 84 BrooK. L. REv. 115, 164 (2018) ("In light of the well documented problems with the criminal justice system for politically powerless groups and knowing what we now know about prison regulation, recognizing an unqualified and unfettered right of public-to-prisoner communication is a necessary step toward transformative criminal justice reform.").

99 Keri Blakinger, Coronavirus Restrictions Stoke Tensions in Lock-ups Across U.S., THE Marshall Project (Apr. 2, 2020), https://www.themarshallproject.org/2020/04/02/corona virus- 
people to tell people in the outside world about the pandemic issues in prisons and jails directly impacts the public response to COVID-19 in carceral spaces.

\section{Speech Within Prison}

Prisons also restrict communication among incarcerated people. I loosely term discussing and planning to express grievances "organizing." In the past, prison organizing has played a pivotal role in the struggle for prisoners' rights. ${ }^{100}$ Strikes often protest inadequate food and medical care or low wages. ${ }^{101}$ Several high profile prison strikes in 1970 led to the establishment of the United Prisoners' Union in California and, then, to additional prison unionizing in prisons on the East Coast. ${ }^{102}$ In a 1977 case challenging a ban on union recruitment in prison, however, the Supreme Court held that prisons may forbid meetings and communication within prisons for security reasons. ${ }^{103}$ The decision was in keeping with the Court's deferential stance to the expertise and security concerns of prison officials, and signaled the difficulty that incarcerated people would continue to face when attempting to organize to advocate for themselves.

The pandemic restrictions further curtailed the extent to which incarcerated people can gather and talk in ways short of forming unions or organized political factions. COVID-19 prison protocols have resulted in some of the longest and most complete lockdowns in decades. ${ }^{104}$ During lockdowns, incarcerated people cannot gather to talk. Social distancing is impossible in most carceral spaces without forcing prisoners to stay in their cells away from common areas. Given the widespread lockdowns, it is all the more remarkable that incarcerated people organized to protest COVID-19 protocols during the pandemic.

restrictions-stoke-tensions-in-lock-ups-across-u-s (describing widespread pandemic lockdowns).

100 Jack E. Call, The Supreme Court and Prisoners' Rights, 59 FED. РROB. 36, 36 (1995).

101 ThOMPSON, supra note 37, 10-11 (discussing how inadequate attention to medical needs was a focal point of complaints in the early Attica organizing efforts); id. at 15-16 (describing metal shop worker strike at Attica resulting in successful negotiation of a wage increase).

102 Sidney Zonn, Inmate Unions: An Appraisal of Prisoner Rights and Labor Implications, 32 U. MiAmi L. REv. 613, 621 (1978) (organizing in California prisons); Frank Browning, Organizing Behind Bars, 10 RAMPARTS 40, 42-43 (1972) (organizing in Massachusetts, New York, and Pennsylvania's prisons).

103 Jones v. N.C. Prisoners Labor Union, Inc., 433 U.S. 119, 132-33 (1977) (ban on union recruitment within prison does not violate First and Fourteenth Amendments).

104 Joseph Shapiro, As COVID-19 Spreads, Lockdowns Spark Fear of More Solitary Confinement, NPR (June 15, 2020), https://www.npr.org/2020/06/15/877457603/as-COVID-spreadsin-u-s-prisons-lockdowns-spark-fear-of-more-solitary-confinemen. 


\section{Talking through the Courts}

Given that normal channels of communication are limited and largely unprotected as a matter of right, incarcerated people have one remaining avenue of protected communication: speaking to the courts. Prisons cannot prevent an incarcerated person from filing a writ of habeas corpus, ${ }^{105}$ or from filing a civil rights suit. ${ }^{106}$ But the right to access courts is often hollow. Incarcerated people suing prisons for civil rights violations or through writs of habeas corpus are almost always self-represented, which presents a practical barrier to effective speech. ${ }^{107}$ Moreover, both habeas corpus petitions and civil rights lawsuits require the plaintiff to overcome significant procedural and substantive hurdles the discussion of which is far beyond the scope of this article. ${ }^{108}$ One hurdle embedded in The Prisoner Litigation Reform Act is, however, directly related to the ability of prisoners to speak

105 Ex Parte Hull, 312 U.S. 546, 549 (1941) (holding that “. . . the state and its officers may not abridge or impair the petitioner's right to apply to a federal court for a writ of habeas corpus.").

106 Wolff v. McDonnell, 418 U.S. 539, 579 (1974) (letters between prisoner and his attorney are privileged and may not be inspected by prison authorities). People serving sentences usually challenge conditions of confinement as violative of the Eighth Amendment's prohibition against cruel and unusual punishment, incorporated in the states via the Fourteenth Amendment. In contrast, pretrial detainees-who may not be punished - challenge conditions of confinement under the due process clause of the Fifth and Fourteenth Amendments. While pretrial detainees may not be punished, Hudson v. Palmer, 468 U.S. 517, 535 (1984), they may be subject to administrative restrictions that serve legitimate governmental objectives. Bell v. Wolfish, 441 U.S. 520, 538-39 (1979).

107 Margot Schlanger, Inmate Litigation, 116 HARVARD L. REV. 1555, 1609 (2003) [hereinafter Inmate Litigation] (noting that in 2000 over $95 \%$ of federal prisoner lawsuits were filed without an attorney). Acknowledging literacy and educational limits, the Supreme Court has emphasized the protected status of jailhouse lawyers, or "writ writers," who, while practicing law without a license, are essential to ensuring that incarcerated people have access to the courts. Johnson v. Avery 393 U.S. 483 (1969) ("Jails and penitentiaries include among their inmates a high percentage of persons who are totally or functionally illiterate, whose educational attainments are slight, and whose intelligence is limited."). To provide access to the courts, prisons must either offer a law library or access to a legal professional. Bounds v. Smith, 430 U.S. 817 (1977) (prisons must "assist inmates in the preparation and filing of meaningful legal papers" through access to law libraries or legal professionals). Yet, the prison may limit advice-giving among incarcerated people. Shaw v. Murphy, 532 U.S. 223 (2001) (upholding disciplinary measures taken against a prisoner who advised another prisoner via letter intercepted by the prison authorities). Moreover, the adequacy of a prison's law library holdings is difficult to challenge because the litigant must show that the dearth of materials in the library "hindered his efforts to pursue a legal claim." Lewis v. Casey, 518 U.S. 343 (1996).

108 For example, less than $0.3 \%$ of habeas petitions in noncapital cases filed in federal court obtain relief. See NANCY J. King et al., Final TeChnical RePORT: Habeas Litigation in U.S. DISTRICT COURTS 9 (2007), https://www.ncjrs.gov/pdffiles1/nij/grants/219558.pdf [hereinafter KING REPORT]. Prisoners usually cannot file another habeas petition after denial of their first. The AntiTerrorism and Effective Death Penalty Act (1996) bars the filing of a second and subsequent habeas petition in federal court. 28 U.S.C. § 2244(d) (1996). The same statute imposes a one-year limit on filing a habeas corpus petition from the date the prisoner has exhausted state remedies. 28 U.S.C. $\S$ 2244(d) (1996). 
through courts. ${ }^{109}$ Federal courts may not entertain an incarcerated person's claims under the PLRA until the prisoner has exhausted the prison administration's grievance procedures. ${ }^{110}$ Predictably, some prisons make it difficult to exhaust grievance procedures, restricting access to grievance forms and failing to respond to grievances in a timely manner. ${ }^{111}$

The exhaustion requirement presents a challenge for COVID-19 litigation. During the pandemic, prisoners reported being unable to access grievance forms or procedures. ${ }^{112}$ Even if they were able to access the forms, the prison's grievance procedure would have taken take too long to be effective. The need for relief to protect from infection was immediate. Compounding the problem, federal courts have interpreted the availability of grievance procedures quite broadly, rejecting the idea that a natural disaster or a pandemic renders an ineffectual grievance procedure "unavailable." 113

Even if prisoner plaintiffs clear the practical and procedural hurdles required to access the courts, they may suffer retaliation from staff, including being "taunted, threatened, transferred to other prisons, removed from coveted work assignments, beaten, and otherwise hassled because of lawsuits they brought against prison officials." 114 In sum, numerous practical barriers impede the ability of incarcerated people to engage in an exchange of information with the outside world, to organize, and to make their complaints heard.

\section{B. Rejecting Speech}

Speech may be discredited after it is heard or rejected preemptively so that it is

109 Prison Litigation Reform Act, Pub. L. No. 104-34, 110 Stat. 1321 (1996).

11042 U.S.C. § 1997e(a) (requiring exhaustion of "such administrative remedies as are available" before challenging prison procedures and conditions in court); Woodford v. Ngo, 548 U.S. 81, 93 (2006) (PLRA requires exhaustion of administrative grievance procedures). A grievance procedure is not, however, considered "available" if it cannot realistically be used. Ross v. Blake, 136 S. Ct. 1850, 1850 (2016); Booth v. Churner, 532 U.S. 731, 736 (2001).

111 As Schlanger puts it, "the sky's the limit for procedural complexity or difficulty of the exhaustion regime." Schlanger, Inmate Litigation, supra note 107, at 1650.

112 Compl. Class Action for Decl. and Inj. Relief and Pet. For Writ of Habeas Corpus at 64-65, Wilson et al. v. Ponce et al., No. 2:20-CV-04451 (C.D. Cal. May 16, 2020).

113 A recent Fifth Circuit decision stayed pending appeal the District Court's imposition of a permanent injunction requiring certain COVID-19 protocols in a unit for elderly and infirm prisoners. Valentine v. Collier, 956 F.3d 797 (5th Cir. 2020). The court rejected the argument that grievance procedures were "unavailable" due to the emergency, even though 500 prisoners had been infected and some had died from COVID-19. The court stated that any grievance procedures, even if inadequate, are still "available," and thus must be exhausted before the court may consider the claim. Id. at 7-8.

114 SCHLANGER ET AL., supra note 107, at 450. 
never heard in the first place. ${ }^{115}$ If the decision to discredit or reject preemptively is based on a categorical mistrust of the speaker as a member of a disfavored social group, it amounts to epistemic injustice. ${ }^{116}$ I will discuss preemptive silencing first, because the reasons it occurs are also the reasons why individual speech acts may be unfairly discredited. I will then discuss discrediting received speech within the context of incarcerated activism.

\section{Preemptive Silencing}

By preemptive silencing I mean the a priori decision that a certain social group has nothing to say worth hearing. An example of this can be found when a public hearing is held about the impact of COVID-19 on prisons without any input from incarcerated people. If the administrative body holding the public hearing accepts the prison's official account of what occurs at the prison while remaining completely incurious about the carceral experience, it amounts to preemptive silencing.

An imaginative structure undergirds the belief that prisoners' complaints should not be entertained. ${ }^{117}$ In the imaginative realm, prisoners are animals or monsters locked in cages so that they cannot harm the public. ${ }^{118}$ The monster mythology serves as a predicate for assuming that incarcerated people do not seek normal things like safety from infectious disease. ${ }^{119}$ The mythology assumes that they seek depraved things and, as a result, their actions will be unpredictable and dangerous. ${ }^{120}$ So, for example, when asked about the jail's failure to provide detainees with masks to protect against airborne infection from COVID-19, the sheriff's spokesperson answered that they could not give detainees masks because

115 See FRICKER, supra note 19, at 1 (defining testimonial injustice as instances when "prejudice causes a hearer to give a deflated level of credibility to a speaker's word"); $i d$. at 130 (discussing "preemptive testimonial injustice").

116 If, on the other hand speech is discredited using acceptable methods of assessing credibility, such as consistency, corroboration, and logic, it cannot be said to be a form of epistemic injustice. Id. at 166.

117 See generally, CAleb Smith, The Prison And the American Imagination (2009) (exploring imaginative understanding of U.S. prisons as a liminal space of death and rebirth).

118 See Joshua Kleinfeld, Two Cultures of Punishment, 68 STAN. L. REV. 933, 1013 (2016) (arguing that "American punishment treats the worst offenders' moral failings as depriving the offenders of their moral humanity-they become, morally speaking, more monsters than persons ....").

119 SмITH, supra note 117, at 28, 30 (describing how prisoners are imagined to be "cadaverous creatures" and "outlaw[s]" who exist on the edge between human and animal).

120 See, e.g., M. Eve Hanan, Incapacitating Errors, 97 DEN. L. REv. 151, 157-59 (2019) [hereinafter Incapacitating] (describing how the mythology of the "superpredator" led to longer prison sentences by defining adolescents who commit crimes as both dangerous and fundamentally incapable of change). 
"they will eat them."121 The mask example highlights how incarcerated people are often imagined as harboring animalistic or monstrous goals that are hidden behind seemingly innocuous requests.

The imaginative view of incarcerated people as monsters has deep roots. For the past fifty years, Americans have been deluged with news, television shows, and movies about violent crime. ${ }^{122}$ The idea that prisons were teeming with ultra-violent criminals melded with the image of the prison population as increasingly Black and Latinx. ${ }^{123}$ Racialized stereotypes that link criminality and dangerousness to Black men and women have even deeper historical antecedents in slavery and convict leasing. ${ }^{124}$ This racialized imagery of criminality is borne out in studies of implicit biases equating African Americans with criminality and dangerousness. ${ }^{125}$

Accordingly, prisons largely serve an incapacitative function. ${ }^{126}$ From the late 1970s through at least 2010, sentencing policy tended toward the goal of "total incapacitation," meaning permanently and completely removing people convicted of crimes - especially violent or repeat crimes - from society. ${ }^{127}$ In keeping with the mythology described above, if prisons are teeming with "creature[s] of unrelenting, unmotivated predatory violence," they should be hermetically sealed to prevent any violent element from contaminating people in the outside world. ${ }^{128}$ Within the imaginative framework of total incapacitation to guard against extreme danger, it is no wonder that safety complaints of incarcerated people would be disregarded.

121 Ashley Remkus, Alabama Jail Refuses Inmates COVID-19 Masks Because "They are going to eat them, " AL.COM (July 9, 2020), https://www.al.com/news/2020/07/alabama-jail-refuses-inmatesCOVID-19-masks-because-theyre-going-to-eat-them.html.

122 Jonathon Simon, Mass Incarceration on Trial: A Remarkable Court Decision and THE FUTURE OF PRISONS IN AMERICA 33-36 (2014) (discussing rise of violent crime theme in news, true crime, and other media sources).

$123 I d$. at 33 (discussing how the historic portrayal of the white prisoner was sympathetic compared to the 1970s portrayal of the "new iconic prisoner, frequently black or brown, [who was seen as] an unchangeable menace barely contained by the prison.").

124 See generally Khalil Gibran Mohammad, The Condemnation of Blackness (2010) (discussing how U.S. crime statistics have historically been deployed to make the racist argument that Black people are prone to criminality).

125 Elsewhere, I have argued that expressions of remorse from Black defendants are likely to be discredited in sentencing hearings due to implicit racial biases. M. Eve Hanan, Remorse Bias, 83 Miss. L. REV. 301, 304-06 (2018).

126 Prison is to "keep dangerous men in safe custody under human conditions." Spain v. Procunier, 600 F.2d 189, 193 (CA9 1979).

127 Simon, supra note 122, at 18, 23 (describing his use of the term "total incapacitation" as the object of sentencing).

128 Id. at 18. I have argued elsewhere that the long prison sentences are contrary to the science of adult development, which demonstrates surprising change in personality, behavior, and brain functioning over the adult lifespan. Hanan, Incapacitating, supra note 120, at 186-89. 
Another aspect of the imaginative life of prisons involves the idea of crime as a contagious disease and prisoners as contaminants who could infect the general population. ${ }^{129}$ During public debates about whether to release prisoners during the pandemic, we heard the argument that, if they are sick with COVID-19, keep them locked in prison in order to keep the outside community safe. ${ }^{130}$ An assistant secretary of health in Louisiana, for example, argued that COVID-19 in prison did not present a public health risk because prisons are "contained" institutions. ${ }^{131}$ Of course, this is not the case. Staff come and go every day. Prison is at once contained within walls and porous - subject to the diseases of the world when employees bring them in and take them out. ${ }^{132}$

By viewing incarcerated people as a source of contamination, we obscure how they can be contaminated. The staff and the public fail to appreciate this risk precisely because the imaginative view of prisoners is of something that contaminates, rather than as someone who can be contaminated. An incarcerated person interviewed in Missouri, for example, complained that the failure of staff to wear masks risked bringing coronavirus into the prison. ${ }^{133}$ In so doing, the incarcerated woman rightly identified that the prisoners were in danger of being contaminated-infected with COVID-19-by the prison staff. Yet, one can imagine - though not endorse - how difficult it might be for prison staff to imagine themselves as the source of dangerous contamination in an ideological regime in which they protect the outside world from metaphorical contamination by prisoners.

The epistemic injustice of prison mythology is this: Viewed primarily as a source of danger and contamination, incarcerated people are unlikely candidates to invite to the public forum, even a forum on issues related to prison administration. Thus, COVID-19 highlights the way in which prisoners and detainees are excluded

129 See Martha Grace Duncan, In Slime and Darkness: The Metaphor of Filth in Criminal Justice, 68 TUlANE L. REV. 725, 751-54 (1994) (discussing how the metaphor of crime as a disease in Western literature leads to the view that criminals are contagious contaminants).

130 California's COVID Prison Outbreak: Gavin Newsome Locks Down the State but Releases Inmates, WALL ST. J. (July 16, 2020), https://www.wsj.com/articles/californias-COVID-prisonoutbreak-11594941334 (editorial arguing that release of prisoners may increase the spread of COVID19 in the community).

131 See Andrea Armstrong, COVID-19 Infections in the Prison System Concern Us All, LOUISIANA ILLUMINATOR (July 12, 2020), https://lailluminator.com/2020/07/12/COVID-19-infectionsin-the-prison-system-concern-us-all/ (criticizing Louisiana's assistant secretary of health for stating that "prisons and jails are not public health risks because they are 'contained"); Kelly Davis, Coronavirus in Jails and Prisons, THE APPEAL (July 13, 2020), https://theappeal.org/coronavirus-injails-and-prisons-30/.

132 GofFMAN, supra, note 35, at 7 (describing the fundamental difference between inmates and staff in "total institutions," like psychiatric hospitals and prisons).

133 Katie Moore, Missouri prison inmates fear COVID being brought in by staff with limited mask policy, KANSAS CITY STAR (July 13, 2020), https://www.kansascity.com/news/coronavirus /article244107457.html. 
as people who can provide knowledge and who have valid complaints. Their status as a public threat renders them both too different and too dangerous to provide information at the same time as it renders them less likely to be seen as vulnerable to danger. ${ }^{134}$

\section{Discrediting Speech}

If speech is heard, the next issue is whether it is believed. Testimonial injustice occurs when someone's claims are disbelieved or discredited because of the speaker's membership in a particular social group. ${ }^{135}$ Their speech is not considered on its merits, using acceptable means of measuring credibility. Rather, their words are discredited due to a group-based prejudice.

Examples abound of discrediting the speech of incarcerated people. The Prison Litigation Reform Act of 1994, for example, was designed in part to reduce the number of frivolous claims. ${ }^{136}$ The discussion of frivolity in the U.S. Senate went beyond the notion that some prisoners' claims lacked legal merit. Attorney Generals created a list of the "top ten" frivolous claims brought by prisoners, which included melted ice cream and the loss of a video game console. ${ }^{137}$ The cherry-picking — and, sometimes, misrepresentation ${ }^{138}$ —of claims seemed designed to portray the use of the courts by incarcerated people as manipulative and frivolous in the ordinary sense of the words, suggesting profound skepticism toward prisoners' credibility.

Within carceral settings, staff discredit the complaints of incarcerated people. Complaints of illness or disability are often met with charges of malingering. ${ }^{139}$ In one incident reported in North Carolina, detainees in the Durham County Detention Center repeatedly pushed an emergency button to notify the staff that a detainee was

134 An exception to my claim that incarcerated people are not seen as victims may be The Prison Rape Elimination Act, which aims to protect incarcerated people from sexual abuse. Prison Rape Elimination Act of 2003, Pub. L. No. 108-79, 117 Stat. 972 (2003).

135 FRICKER, supra note 19, at 17-21.

136141 Cong. REC. S14611-01 (daily ed. Sept. 27, 1995) (statement of Sen. Hatch arguing that "[j] ailhouse lawyers with little else to do are tying our courts in knots with an endless flood of frivolous litigation"); Schlanger, Inmate Litigation, supra note 107, at 1565-66 (pointing to concern over frivolous litigation as a primary driver of the PLRA).

137141 Cong. REC. S14611-01 (daily ed. Sept. 29, 1995), at*S14629 (Westlaw).

138 Jon O. Newman, Pro Se Prisoner Litigation: Looking for Needles in Haystacks, 62 BROOK. L. REv. 519, 520-21 (1996) (citing appellate judge who researched the list finding that senator's descriptions were "misleading" or "false").

139 See, e.g., Jamelia N. Morgan, Reflections on Representing Incarcerated People with Disabilities: Ableism in Prison Reform Litigation, 94 DENV. L. REv. 973, 982 (2019) (discussing how incarcerated people may be viewed as malingering when making complaints of certain illnesses or disabilities considered "nonserious"). 
having a seizure. ${ }^{140}$ Although the staff heard the emergency calls, they ignored them because they believed that the detainees were making false claims of emergency to trick the staff. ${ }^{141}$ In this case, as well as in similar cases in the same detention facility, the detainee died without medical assistance. ${ }^{142}$ The speech-a call for help-was discredited based on blanket disbelief of detainee complaints.

To further complicate matters, the discredited complaints of incarcerated people may be used as evidence of their poor adjustment to carceral life. Goffman describes this process as "looping." 143 An incarcerated person's complaint is viewed as proof of the person's failure to adjust to the rules of the institution rather than as an institutional failure.

The looping problem is magnified in organized protest. Just like individual complaints, organized grievances may be viewed as evidence of the prison population's failure to adjust rather than as evidence of the prison's failings. The prison uprisings of the early 1970s, for example, met with divided public opinion. ${ }^{144}$ For some, "the murderous reprisals [by guards] confirmed their worst fears about the authoritarian intentions of the prison establishment." ${ }^{145}$ For others, the rebellions stoked fears of crime and criminals, leading to greater support for prisons and long prison sentences. ${ }^{146}$ In the end, the latter opinion won the day: The act of protesting seemed to prove that the prisoners were dangerous. Concerns about rising crime rates and dangerous criminals fed into the "total incapacitation" approach to sentencing and prisons described earlier. ${ }^{147}$ In this way, voicing grievances often backfires.

In the context of the pandemic, testimonial injustice can be seen in crediting official accounts of pandemic protocols over the accounts of incarcerated people. Journalists have noted the gulf between official and prisoner accounts of pandemic protocols. ${ }^{148}$ On occasion, incarcerated people have provided the press with

140 José Medina, Agential Epistemic Injustice and Collective Epistemic Resistance in the Criminal Justice System, Social EPISTEMOlogy 1, 3 (2020), https://doi.org/10.1080/02691728 .2020 .1839594 .

141 Id.

$142 I d$.

143 GofFMAn, supra note 35, at 35-36 ("The individual finds that his protective response to an assault upon self is collapsed into the situation; he cannot defend himself in the usual way by establishing distance between the mortifying situation and himself.").

144 SimON, supra note 122, at 27.

$145 I d$.

146 Id. at 32.

147 Id. at 41.

148 Keri Blakinger \& Joseph Neff, Thousands of Sick Federal Prisoners Sought Compassionate Release. 98 Percent Were Denied, The Marshall Project (Oct. 7, 2020), https://www.themarshall project.org/2020/10/07/thousands-of-sick-federal-prisoners-sought-compassionate-release-98- 
surreptitious recordings from the prison only to have the prison deny the recorded occurrence. ${ }^{149}$ The Marshall Project reported receipt of a cell phone video from a Texas prison showing fires allegedly started by prisoners who were protesting that they had no electricity or bathing water. ${ }^{150}$ The fires were designed to get the attention of prison authorities higher up the chain of command. ${ }^{151}$ The prison authorities, however, told the journalists that the prison had no record of the fires or any other actions protesting the electrical failure. The Marshall Project ran the story without confirmation from prison authorities, but other publications may decide not to publish similar evidence from incarcerated people without corroboration. ${ }^{152}$

Individual requests for release due to increased risk of COVID-19 complications also may be viewed with suspicion. A public narrative has emerged that incarcerated people are using the pandemic as an illegitimate excuse to secure release. Colorado Governor Jared Polis, for example, responded to a prisoners' lawsuit for early release due to COVID-19 by stating that the "pandemic is no excuse to let criminals out." 153

In summary, incarcerated people face practical, legal, and credibility barriers when they try to share information about what is happening inside carceral spaces. COVID-19 highlights how quickly customary communication methods can be taken away without running afoul of the constitution under existing caselaw. The pandemic also offers clear examples of how incarcerated people are ignored or disbelieved when they seek relief from dangerous conditions of confinement. Finally, the pandemic shows the profound need for the outside world to hear what incarcerated people have to say about what is happening inside their facilities. The next section addresses just that: how incarcerated people have advocated for themselves in the pandemic despite the obstacles described above.

percent-were-denied (noting prosecutor who opposed compassionate release thought the prison's coronavirus protocols were adequate "despite widespread reports to the contrary").

149 Keri Blakinger, Coronavirus Restrictions Stoke Tensions in Lock-ups Across U.S., THE MARShALl PROJECT (Apr. 2, 2020), https://www.themarshallproject.org/2020/04/02/coronavirusrestrictions-stoke-tensions-in-lock-ups-across-u-s.

$150 I d$.

151 Id.

152 See Reuters, HandBook of Journalism: The EsSEntials of Reuters Sourcing (Clive McKeef ed., last updated Feb. 7, 2017, 10:41 PM), http://handbook.reuters.com/index.php? title=The_Essentials_of_Reuters_sourcing\&direction=prev\&oldid=7962 (stating "[s]tories based on a single, anonymous source should be the exception and require approval by an immediate supervisor, such as a bureau chief or editor in charge.").

153 Jesse Paul, Colorado Governor Defends Prison System, Accuses ACLU of Using Coronavirus to Push Its Agenda, COLORADO Sun (May 28, 2020), https://coloradosun.com/ 2020/05/28/jared-polis-coronavirus-briefing-may26-prisons-inmates/. 


\section{EPISTEMIC AGENCY IN A PANDEMIC}

"[S]peaking when silence is expected ... such acts became for Robby a discipline, a systemic resistance to preserve dignity and self-worth." 154

Despite heightened epistemic impediments produced by pandemic-related restrictions, the first few months of the COVID-19 pandemic saw a surge of activism in prisons and jails. The focus of demands has been four-fold: (1) to improve internal safety protocols that will reduce the spread of the virus; ${ }^{155}$ (2) to impose safety protocols in a way that does not require total isolation through lockdowns; ${ }^{156}$ (3) to release incarcerated people who are vulnerable to COVID-19's more serious complications $;{ }^{157}$ and (4) to reduce the overall number of people in prison and jail so that social distancing is possible. ${ }^{158}$ Importantly, these challenges brought by incarcerated people have been both political and legal. In many of the challenges, allies outside of prison play a pivotal role in the success of incarcerated voices reaching their intended audience. These allies may be prison volunteers, family, friends, journalists, activists, or lawyers.

I do not mean to portray a rosy picture in which activism leads inevitably to meaningful change. Despite the surge in activism by incarcerated people and on their behalf, success has been limited. Given the impossibility of social distancing in prisons and jails, incarcerated people have found themselves in long-term lockdowns and yet have still witnessed COVID-19 positivity rates far exceeding the rates in the U.S. population at large. ${ }^{159}$ Lawsuits seeking release or transfer tend to meet with limited success after great effort. ${ }^{160}$

154 John Edgar Wideman, Brothers And KeEpers, at xvii (First Mariner Books 2005) (emphasis added) (describing his observations of his brother, who was incarcerated for life).

155 See, e.g., Hallinan et al. v. Scarantino., 466 F.Supp.3d 587 (E.D.N.C 2020).

156 See, e.g., Joseph Shapiro, As COVID-19 Spreads in Prisons, Lockdowns Spark Fear Solitary Confinement, NPR (June 15, 2020), https://www.npr.org/2020/06/15/877457603/as-COVID-spreadsin-u-s-prisons-lockdowns-spark-fear-of-more-solitary-confinement.

157 See, e.g., Alice Speri, Prison Officials in Kansas Ignored the Pandemic. Then People Started Dying., THE INTERCEPT (Oct. 1, 2020), https://theintercept.com/2020/07/02/coronavirus-kansas-prisonlansing-correctional/.

158 See, e.g., Torres v. Milusnic, 472 F.Supp.3d 713 (C.D. Cal 2020).

159 One in every five prisoners in US has tested positive for Covid-19, ASSOCIATED PRESS (Dec. 18, 2020 12:12 PM), https://www.theguardian.com/us-news/2020/dec/18/us-prisoners-coronavirusstats-data.

160 For example, advocates filed state habeas corpus petitions for individual prisoners in San Quentin in April and May of 2020. On October 20, 2020, a California appellate court held that the state acted with deliberate indifference to the risk of COVID-19 for a vulnerable prisoner and ordered transfer or release. In re Ivan Von Staich, A160122 (Oct. 20, 2020), https://www.courts.ca. gov/opinions/documents/A160122.PDF. The decision requires San Quentin to release or transfer 50\% 
Legislative and executive action has been similarly limited. In the federal prison system, the CARES Act expanded eligibility for home confinement and compassionate release. ${ }^{161}$ While more than 7,500 transitioned to home confinement, ${ }^{162}$ fewer than $2 \%$ of applications for compassionate release have been granted. ${ }^{163}$

Some states have reduced prison populations, although not by much. Pennsylvania, for example, started a temporary reprieve program in April of 2020 that permits release of some prisoners until the end of the pandemic. ${ }^{164}$ The governor must approve each release, and only 160 people out of 1,200 people recommended by the corrections department were released in the first three months. ${ }^{165}$ California's Governor Newsom ordered the release of 8,000 prisoners. ${ }^{166}$ Hadar Aviram points out, however, that releasing just 8,000 people is inadequate against the backdrop of prior failures to reduce the California prison population to the numbers required by the Supreme Court in Brown v. Plata. ${ }^{167}$ While jail populations have been reduced with more success through county-level decisions, prisons remain largely unchanged. ${ }^{168}$

of its prisoners. Many other cases from around the country, whether brought as civil rights actions or habeas claims, are still pending or have been unsuccessful. For a complete list of lawsuits, see UCLA COVID-19 Behind Bars Data Project, https://docs.google.com/spreadsheets/d/1X6uJkXXS-O6 eePLxw2e4JeRtM41uPZ2eRcOA_HkPVTk/edit\#gid=708926660.

161 Coronavirus Aid, Relief, and Economic Security Act (CARES Act), Pub. L. No. 116-136, Sec. 12003(b), 134 Stat. 281, 516 (2020).

162 According to the Federal Bureau of Prisons' website, 7,822 prisoners were placed on home confinement. COVID-19 Corona Virus, FED. BuREAU OF PRISONS, https://www.bop.gov/corona virus/index.jsp (last visited Oct. 13, 2020). It is unclear the number of prisoners included in the total who would have been transferred to home confinement regardless of the national emergency declared.

163 Blakinger \& Neff, supra note 148 (reporting that just 156 of the 10,940 prisoners who applied for compassionate release between March and May 2020 were approved by their wardens).

164 Damini Sharma et al., Prison Populations Drop by 100,000 During Pandemic, THE MARShall PROJeCt (July 16, 2020, 7:00 AM), https://www.themarshallproject.org/2020/07/16/pris on-populations-drop-by-100-000-during-pandemic.

$165 I d$.

166 CDCR Announces Additional Actions to reduce Population and Maximize Space Systemwide to Address COVID-19, CALIFORNia DeP't of CoRRECTIONS AND Rehabilitation (July 10, 2020), https://www.cdcr.ca.gov/news/2020/07/10/cdcr-announces-additional-actions-to-reduce -populationand-maximize-space-systemwide-to-address-COVID-19/.

167 Hadar Aviram, California's COVID-19 Prison Disaster and the Trap of Palatable Reform, Boom CALIFORnia (Aug. 10, 2020), https://boomcalifornia.com/2020/08/10/californias-COVID-19prison-disaster-and-the-trap-of-palatable-reform/.

168 See, e.g., Responses to the COVID-19 Pandemic, PRISON POL'Y. InITIATIVE (last updated Feb. 5, 2021) https://www.prisonpolicy.org/virus/virusresponse.html (noting that prisons, unlike jails, "are releasing almost no one" in response to the pandemic). 
In this Part, I describe examples of epistemic agency in a few, key areas, but by no means provide an exhaustive account of prisoner activism and advocacy during the pandemic. Despite official denials, some prisoner and detainee accounts of carceral conditions during the pandemic have been credited by some news sources and courts. Finally, I offer some preliminary thoughts about what is powerful in the aggregation of accounts provided by incarcerated people. Aggregated accounts of pandemic conditions undergird many of the current lawsuits and may play a pivotal role in political action as well.

\section{A. Speaking $U p$}

Despite restrictions in place in many prisons, incarcerated people have contacted journalists through prison email systems to report pandemic hardship, like the absence of programming and severely restricted communication with others inside and outside the prison. ${ }^{169}$ Others have placed telephone calls directly to reporters, sometimes leading to official reprisals. ${ }^{170}$ Another method of reporting from prison has been through contraband cellphones, sharing videos of "men packed together in their cubicles, sleeping and wheezing." 171 Some have also spoken out about jail conditions after they are released. ${ }^{172}$

Family members and others on the outside often serve as epistemic allies who amplify the voices of incarcerated people. ${ }^{173}$ With increased communication challenges during the pandemic, incarcerated people have communicated about

169 For example, an incarcerated person in Michigan emailed Salon magazine about pandemic changes in prison, including the pains of seeing people die, losing the ability to communicate with one another, and losing the programming that made life tolerable. Shearod MacFarland \& Mateo Hoke, Pandemic and Prison: Shearod McFarland, Incarcerated in Michigan, On What COVID-19 Has Changed, SALON (July 11, 2020), https://www.salon.com/2020/ 07/11/pandemic-and-prison-shearodmcfarland-incarcerated-in-michigan-on-what-COVID-19-has-changed/.

170 Anna Merlan, Women at Oregon Prison Say Their Lives Are at Risk After COVID-19 Patients Are Transferred In, VICE (Apr. 9, 2020), https://www.vice.com/en/article/7kzyed/women-at-oregonprison-say-their-lives-are-at-risk-after-COVID-19-patients-are-transferred-in (While officials deny the occurrence, one prisoner claims that she was placed in segregation for seven days for contacting reporters at Vice.).

171 Keri Blakinger \& Keegan Hamilton, I Begged Them to Let Me Die, The Marshall ProjeCt (June 18, 2020), https://www.themarshallproject.org/2020/06/18/i-begged-them-to-let-me-die-howfederal-prisons-became-coronavirus-death-traps (reporting on videos taken by prisoners in Ohio and Michigan).

172 Protesters detained in Alabama reported that their masks were confiscated upon arrest; they were not provided with new masks; and the jail staff refused to wear masks. Ashley Remkus, Alabama Jail Refuses Inmates COVID-19 Masks because "They are going to eat them," AL.COM (last updated July 9, 2020), https://www.al.com/news/2020/07/alabama-jail-refuses-inmates-COVID-19-masksbecause-theyre-going-to-eat-them.html.

173 Medina, Agential Epistemic Injustice, supra note 140, at 194. 
conditions of confinement through family members. ${ }^{174}$ José Medina discusses, for example, a partnership between people incarcerated at a local jail and their lay advocates on the outside. ${ }^{175}$ The detainees wrote letters describing the lack of COVID-19 safety protocols, which the lay advocates read in city council and county commission meetings. ${ }^{176}$

Some media outlets have epistemically aided incarcerated people by publishing their reports of carceral conditions. ${ }^{177}$ An incarcerated journalist at San Quentin interviewed other incarcerated men about their inability to socially distance in a prison whose residents are "jammed in like sardines in a can." 178 In another example, incarcerated journalist Peter Debelak described lack of access to information about the pandemic, little paper on which to write letters, few permitted phone calls, and prisoners "shoulder to shoulder" in common areas. ${ }^{179}$ Some newspapers have gone so far to create forums for the narratives of incarcerated people during the pandemic, such as the oral history of the outbreak in a federal prison in Oakdale, Louisiana, that appeared in the New York Times. ${ }^{180}$

Incarcerated people have also attempted to attract the attention of the media through protests and strikes, as I describe in the Introduction. ${ }^{181}$ People detained by Immigration and Customs Enforcement (ICE) have conducted numerous hunger

174 See, e.g., Jake Harper, In Lockdown, Conditions at Indiana Women's Prison Unhealthy, Advocates Say, SiDE EFFECTS (June 25, 2020), https://www.sideeffectspublicmedia.org/post/ COVIDlockdown-conditions-indiana-women-s-prison-unhealthy-advocates-say (friend of a woman currently incarcerated in the prison relayed that her incarcerated friend was told to urinate in a cup when the water shut off).

175 Medina, Agential Epistemic Injustice, supra note 140, at 11.

$176 I d$.

177 E.g., Christopher Blackwell, In Prison, Even Social Distancing Rules Get Weaponized, THE Marshall Project (May 28, 2020 10:00 PM), https://www.themarshallproject.org/ 2020/05/28/inprison-even-social-distancing-rules-get-weaponized (describing impossible-to-follow social distancing rules becoming grounds for infractions).

178 Juan Morena Haines \& Elizabeth Weill-Greenberg, At San Quentin, Overcrowding Laid the Groundwork for an Explosive COVID-19 Outbreak, THE APPEAL (July 21, 2020), https://theappeal.org/ at-san-quentin-overcrowding-laid-the-groundwork-for-an-explosive-COVID-19-outbreak/ (interviewing three men about inadequate pandemic protocols at San Quentin).

179 Peter Debelak, We Would Die of the Virus or Not. The System Would Roll On, N.Y. TimeS (June 27, 2020), https://www.nytimes.com/2020/06/27/opinion/prison-coronavirus.html.

180 E.g., Janet Reitman, "Something Is Going to Explode": When Coronavirus Strikes a Prison, N.Y. TIMES (Apr. 23, 2020), https://www.nytimes.com/2020/04/18/magazine/oakdale-federal-prisoncoronavirus.html (first person accounts from prisoners and staff).

181 Paul Blest, Inmates at Prison Plagued by COVID Live-Streamed Uprising on Smuggled Cell Phones, ViCE (Aug. 3, 2020), https://www.vice.com/en/article/qj4xpp/inmates-at-prison-plagued-byCOVID-live-streamed-uprising-on-smuggled-cell-phones (documenting pandemic-related uprising at Ware State Prison). 
strikes during the pandemic. ${ }^{182}$ Detainees awaiting trial in criminal cases have engaged in pandemic-related hunger strikes as well. ${ }^{183}$ For example, detainees at the San Mateo jail in California held a successful ten-day hunger strike for expanded phone and video visits and an end to price-gouging in the commissary. ${ }^{184}$ Allies of the detainees held simultaneous protests outside of the jail, one holding a sign reading, "Your voice is not lost.", 185

\section{B. Corroboration and Aggregation}

Amid this surge of speech and protest is the question whether incarcerated accounts of pandemic conditions will be believed. Carceral accounts of COVID-19 often challenge the official narrative. ${ }^{186}$ And, it can be difficult to piece together what is happening when the prison administration denies the claims of the prisoners. ${ }^{187}$ Journalists have looked to formerly incarcerated people and prison staff to corroborate reports from within carceral spaces. An article about a women's prison in Indiana, for example, relied on a former prison staff member to corroborate excessive heat and lack of running water, and relied on a former inmate to corroborate the lockdown. ${ }^{188}$ Presumably, some accounts of incarcerated people

182 See, e.g., Dara Lind, ICE Detainee Says Migrants Are Going on a Hunger Strike for Soap, ProPublica (Mar. 23, 2020), https://www.propublica.org/article/ice-detainee-says-migrants-aregoing-on-a-hunger-strike-for-soap. Reports of hunger strikes in ICE detention predate the pandemic. See, e.g., Matthew Hendley, Immigration Detainees Go on Hunger-Strike Over Conditions at Pinal County Jail, PHOENIX New TIMES (June 13, 2014), https://www.phoenixnewtimes.com/news/ immigrant-detainees-go-on-hunger-strike-over-conditions-at-pinal-county-jail-6650744.

183 Robert Salonga, Santa Clara County Jail Inmates, Families Launch Hunger Strike to Protest Conditions, MERCURY NEws (Aug. 14, 2020, 1:16 PM), https://www.mercurynews.com/ 2020/08/14/santa-clara-county-jail-inmates-families-launch-hunger-strike-to-protest-conditions/ (describing how a detainee hunger strike was supported by family and friends holding a protest outside of the jail).

184 Kate Bradshaw, San Mateo County Inmates Win Demands After 10-Day Hunger Strike, AlmanaC (June 26, 2020), https://www.almanacnews.com/news/2020/06/26/san-mateo-countyinmates-win-demands-after-10-day-hunger-strike.

185 Id.

186 In one case, for example, prison authorities reported twice-a-day temperature checks, but an incarcerated woman reported less than two checks per week and a complete unavailability of further medical care for women displaying symptoms. Alexandra DeLuca, Loved Ones and Prisoners Sound Alarm as Coronavirus Cases Surge at Florida's Largest Women's Prison, THE APPEAL (Aug. 21, 2020), https://theappeal.org/loved-ones-and-prisoners-sound-alarm-as-coronavirus-cases-surge-at-flor idas-largest-womens-prison/.

187 Id.

188 Jake Harper, In Lockdown, Conditions at Indiana Women's Prison Unhealthy, Advocates Say, SidE EFFECTS (June 25, 2020), https://www.sideeffectspublicmedia.org/post/COVID-lockdownconditions-indiana-women-s-prison-unhealthy-advocates-say. 
cannot be corroborated, and thus go unpublished by established journalists.

Yet, current attention to the pandemic-related accounts of incarcerated people, by the media and, in some cases, by government bodies, suggests a heightened interest in their claims and a willingness to search for corroboration. ${ }^{189}$ The sheer number of similar claims about prison and jail conditions during the pandemic seems to add to their credibility. As of August 28, 2020, the UCLA Law COVID Behind Bars Project listed 569 legal actions related to the coronavirus filed on behalf of incarcerated people. ${ }^{190}$ Certainly, many more incarcerated people have petitioned courts for writs of habeas corpus, and governors and parole boards for early release due to age or particular health variables that increase vulnerability to serious complications from COVID-19. ${ }^{191}$

Class action lawsuits seeking injunctive relief in the form of release from incarceration and better pandemic protocols provide an example of how the accounts of incarcerated people can be organized and aggregated to serve an epistemic function. In one case, a U.S. District Court granted a temporary injunction, agreeing that the plaintiff detainees demonstrated a reasonable likelihood of success in showing at trial that the jail created an "unreasonable risk" of COVID-19. ${ }^{192}$ While the court cited to statistics and other sources, it also cited the declarations of detainees alleging that (1) they were not able to socially distance; (2) they were not given sick slips to request medical attention; and (3) they were not given hygiene products to clean their cells and their bodies. ${ }^{193}$

In another case challenging COVID-19 protocols under the Eighth Amendment, the court cited to a prisoner's declaration when discussing the likelihood of success on the merits. ${ }^{194}$ The court noted that the prisoner reported a lack of social distancing due to the "physical configuration" of the facilities, which

189 For example, the Louisiana State Subcommittee on COVID-19 June 15, 2020 report specifically elicited information from incarcerated people. The report contains the image of a letter describing inadequate medical care for a heart condition of a prisoner with COVID-19. COVID-19 Special Populations-La. Prisons, Subcomm. Final Rep. June 15, 2020, reprinted in July COVID TASK FoRCE SUBCOMM. REP. 1, 3 (2020), https://www.sus.edu/assets/ sus/LAHealthEquityTaskForce/ JULY-COVID-Task-Force-Subcommittee-Reports.pdf.

190 COVID-19 Behind Bars Data Project, UCLA (last visited Aug. 28, 2020), https://docs.google.com/spreadsheets/d/1X6uJkXXSO6eePLxw2e4JeRtM41uPZ2eRcOA_HkPVTk/edit\#gid=708926660.

191 An example of a mechanism for individuals to petition for release is the federal compassionate release program, which was amended to permit COVID-19 related release. Co. Coronavirus Aid, Relief, and Economic Security Act (CARES Act), Pub. L. No. 116-136, Sec. 12003(b), 134 Stat. 281, 516 (2020).

\footnotetext{
192 Banks v. Booth, 459 F.Supp.3d. 143, 154-55 (D.D.C. 2020).

193 Id.

194 Torres, 472 F.Supp.3d at 727-28.
} 
the court agreed "precludes meaningful social distancing." 195 In discussing whether the plaintiffs had a reasonable likelihood of proving that the prison officials acted with deliberate indifference, the court relied on a prisoner's declaration stating that a case manager told him that his request for compassionate release would be shredded rather than forwarded to the warden. ${ }^{196}$

While the court was not adjudicating the ultimate issues in its order for a temporary injunction, and, thus, not making a credibility determination, the use of prisoners' allegations is still significant from an epistemic perspective. Successful civil rights lawsuits may "initiate and nurture political mobilization" among incarcerated people. ${ }^{197}$ Well publicized legal victories have historically "politicized prisoners and heightened their expectations." 198 Moreover, the collection of declarations from incarcerated people points to another bridge between legal and political challenges. The voices of incarcerated people, referenced in judicial orders, became part of the public discussion about prison conditions.

Viewing the declarations outside of the context of their legal function, they are quite breathtaking. They provide multiple, granular accounts of what is happening inside of prisons and jails during the pandemic. The accounts are more likely to be credited because there are so many of them. Where a few complaints can be discounted or discredited, numerous, detailed accounts of prison are less easy to dismiss or ignore. The aggregation of incarcerated narratives may overcome epistemic injustice in the political sphere as well as the legal sphere. Moreover, speaking as an organized collective would be more effective in mobilizing political power than individual stories shared with journalists. It is, however, precisely this kind of organized activism that prisons often forbid as detrimental to prison security. And, during the pandemic, physical opportunities to organize informally have been even more limited by lockdowns.

In Part III, I elaborate on how organized, aggregated speech from incarcerated people is needed in the political sphere to increase accountability within carceral spaces and to improve the quality of public debate about criminal legal practices. Yet, this type of organized effort is rendered exceptionally difficult by the limited rights of prisoners to speak and organize.

195 Id. The court also relied on a prisoner declaration regarding availability of medical treatment and difficulties social distancing in the dormitories and during mealtime. $I d$. at 728 . warden).

196 Id. at 739 (the complainant did not receive written response from the case manager or the

\footnotetext{
197 Jacobs, supra note 23.

198 Id. at 460.
} 


\section{CONTESTING AUTHORITARIAN INSTITUTIONS}

"I tried to write several times in these last couple of weeks, but my letters all came back with a note attached explaining what I can and cannot say."199

In this final Part, I make the broader argument that incarcerated speech is essential to the kind of political discussions that should take place in a democracy. I use the term "political" to "refer to the vital project of negotiating how we live together as a city, a state, or country; of working across difference; of acting collectively." ${ }^{200}$ In the autocratic arena of prisons, however, political speech is not guaranteed and often not possible. ${ }^{201}$

The reader might point out that prisons are not intended to be democratic institutions. The punishment intended by incarceration is a loss of liberty, which includes the curtailment of many rights enjoyed by others in the U.S. ${ }^{202}$ Even pretrial detainees forfeit rights that conflict with legitimate governmental objectives. ${ }^{203}$ While incarceration subordinates individual rights to penological or administrative objectives, this feature leaves prisons and jails with the weakness of authoritarian regimes as well. ${ }^{204}$

First, because of the total vulnerability of incarcerated people, their inability to have their complaints heard leads to fatal errors during emergencies. ${ }^{205}$ Second, prisoner speech could provide an important check on governmental abuse of power and provide a clearer picture of prison conditions to the public. ${ }^{206}$ It thus limits how

199 George Jackson, Soledad Brother: The Prison Letters of GeOrge JaCKSON 101 (1994) (in a letter from incarcerated George Jackson to his brother).

200 Masha Gessen, Surviving Autocracy 98 (2020).

201 Id. at 155 ("One did not notice the disappearance of political speech immediately-it was like an object that, by the time one realizes it is gone, has been absent for some time.").

202 See, e.g., Hudson v. Palmer, 468 U.S. 517 (1984) (prisoners forfeit right to privacy).

203 Bell v. Wolfish, 441 U.S. 520, 538-39 (1979).

204 In the mid-century authoritarian regimes of Eastern Europe, for example, members of the public could not start a newspaper, write a letter to the editor critiquing the regime, donate money to an opposition party, or even sign a petition. Hank Johnston, Talking the Walk: Speech Acts and Resistance in Authoritarian Regimes, in 21 REPRESSION AND MOBILIZATION 108, 117 (Christian Davenport et al. eds., 2005).

205 This point is similar to Erwin Chemerinsky's argument for applying a less deferential standard to the analysis of when prison rules violate constitutional rights. Erwin Chemerinsky, The Constitution in Authoritarian Institutions, 32 SufFolK U. L. REV. 441 (1999) (arguing that prisoners are a discrete, insular minority with virtually no ability to politically challenge the rules governing them). Gesturing to the Stanford Prison Experiment, he notes how quickly those assigned the role of guard will begin to abuse people assigned the role of prisoner. Id. at 458 .

206 See No Prisoner, supra note 27, at 466-69 (discussing the arguments for and against greater transparency in prisons). 
people engaged in public discussions understand what is happening in prisons. Third, and closely related to the second point, the inability of incarcerated people to participate in public discussions threatens the larger democracy. I address these points below.

\section{A. Retaliation for Speaking Up}

Official responses to incarcerated activism often treat grievances as threats to the power structure and, thus, respond not only by denying relief, but also by punishing those seeking democratic participation. ${ }^{207}$ Emblematic of authoritarian restrictions on political participation, prisons, and jails not only limit speech and organizing, but also may retaliate against incarcerated people who lodge internal grievances or external complaints. ${ }^{208}$

It is helpful to look at the history of prison organizing to see how prisons become more repressive in response to protest. The legal recognition of prisoners' rights evolved out of litigation in the 1960 s and early $1970 \mathrm{~s} .{ }^{209}$ The early 1970 s were a moment in which prisoners were close to achieving a political voice that could check government abuses and correct distortions in the public discourse about crime, punishment, and prisons. ${ }^{210}$ Indeed, unionization efforts in prisons could have resulted in prisoners becoming a powerful political force. ${ }^{211}$

Yet, authoritarian backlash against incarcerated activism came swiftly on the heels of politically active prisoners. ${ }^{212}$ When incarcerated people in New York's prisons began organizing to demand basic necessities, such as competent medical and psychiatric care, sanitary conditions, an improved law library, and fair parole procedures, prison authorities were largely unresponsive. ${ }^{213}$ Although the state's prisoners and detainees attempted to engage in a democratic process, their demands

207 ThOMPSON, supra note 37 , at 33 (“[A]dministrators decided that the best response to [a demand list] was to clamp down even harder on the prison population.").

208 Agential Epistemic Injustice, supra note 140, at 190 (describing how detainees were reluctant to file grievances due to reprisals for previous grievances).

209 Jacobs, supra note 23, at 434-35 (noting that First Amendment challenges raised by incarcerated Black Muslims "brought the federal courts into the prisons"). By 1974, the Supreme Court stated that "[t]here is no iron curtain drawn between the Constitution and the prisons of this country." Wolff v. McDonnell, 418 U.S. 539, 555-56 (1974).

210 See Racial Origins, supra note 12, at 236-42, 248-57 (discussing the power of the prison protest movement in relation to unionizing and the civil rights movement, respectively).

211 See Dolovich, supra note 18, at 247 (describing how prison unions could have become a "power bloc").

212 In fact, repressive regimes deliberately suppress political speech to maintain power and suppress nonviolent political contention. Johnston, supra note 204, at 108.

213 Thompson, supra note 37, at 22-23 (listing the demands of the Auburn prisoners who had taken fifty staff and civilian workers hostage in the yard). 
were met with suspicion. ${ }^{214}$ Even simple strikes for higher wages led politicians and prison officials to characterize prison activists as communists posing a national threat. ${ }^{215}$ This appears to have been a deliberate misreading of the complaints of incarcerated activists seeking fair wages and better living conditions. ${ }^{216}$

When unmet demands led to uprisings, as they did in Attica in 1971, local authorities often suppressed the protests with violence rather than negotiating solutions. The uprising in Attica ended when New York state troopers took off their badges and stormed the prison, shooting prisoners and hostages alike, while shouting racial epithets. ${ }^{217}$ Brutal and often deadly retaliation against prisoners persisted in Attica for weeks, if not years. ${ }^{218}$ In the aftermath, the state of New York spun the uprising as a story of militant, Black prisoners who were highly dangerous and who required severe repressive measures. ${ }^{219}$ Prison administrators used the Attica uprising to argue that prison administration should not engage in negotiations, but, instead, should crack down to prevent protest and organizing in prisons. ${ }^{220}$

Thus, while Attica demonstrated the "power and possibility of prisoner rights activism," it also, "Janus-like... reflected, and helped to fuel, a historically unprecedented backlash against all efforts to humanize prison conditions in America." ${ }^{221}$ Indeed, as discussed earlier in this essay, several years after the Attica uprising, the Supreme Court made clear that prison administrators can prevent prisoners from organizing if the restrictions are reasonably related to legitimate penal interests. ${ }^{222}$ This combination of violent suppression of protest and Supreme Court deference can be said to teach an authoritarian lesson: Protest leads not to changed circumstances but to reprisals and repression. Protests lead the authoritarian institution to conclude that it should exercise more domination and control. ${ }^{223}$

The repression of speech is dangerous for those dependent on the institution for

214 Id. at 32-33.

215 Id. at 21 (discussing New York Governor Rockefeller's response to jail and prison strikes and protests in 1970).

$216 I d$.

217 Id. at $182-86$.

218 Id. at 206-07; id. at 217 (the prison superintendent refused to allow volunteer medical personnel to enter the prison, presumably to prevent them from seeing what had occurred).

219 See Racial Origins, supra note 12, at 254-55 (describing a 1971 New York Times article characterizing protests in prison as being led by Black men affiliated with the Black Panther Party).

220 ThOMPSON, supra note 37, at 562.

221 Id. at 561 .

222 Jones v. North Carolina Prisoners' Labor Union, Inc., 433 U.S. 119 (1977).

223 See generally Steven Heydemann \& Reinoud Leenders, Authoritarian Learning and Authoritarian Resilience: Regime Responses to the 'Arab Awakening, ' 8 GlobALIZATIONS 647 (2011) (discussing strategies of authoritarian regimes in repressing or waiting out uprisings). 
survival. A prison is a "total institution" in which the lives of its captive residents are completely structured by the institution. ${ }^{224}$ It requires its residents to ask permission for tasks and supplies that are normally within the easy control of any adult, such as the ability to decide when to wake up, to drink water, or to make a telephone call. ${ }^{25}$ In response to requests, the staff may further impress upon incarcerated people their absolute vulnerability by refusing, delaying, questioning, or teasing rather than providing the requested item or permission. ${ }^{226}$ In the Durham jail example described earlier, in which the jail staff failed to respond to calls for help during a detainee's fatal seizure, the total vulnerability of the detainee was fatal.

This same wedding of total vulnerability and discredited complaints can be seen during the pandemic as incarcerated people beg and sometimes riot for masks, hand sanitizer, and soap. ${ }^{227}$ Because of the design of carceral spaces-tightly packed people relying on the institution to meet all basic necessities - COVID-19 spreads exponentially. Yet, incarcerated people, who are experiencing heightened danger from coronavirus, are the least able to advocate for themselves or influence public policy. And, when they do advocate for themselves, they rightly fear retaliation.

\section{B. Talking and Democracy}

The ability to express one's views on official matters is what assures minimal access to the political sphere, which, in turn, functions as a check on government power and an enhancement to public debate. ${ }^{228}$ Freely criticizing the government protects against the distortion of the political process that can result when certain viewpoints are omitted from public discourse. ${ }^{229}$ As Bianchi and Shapiro state, "[w]ithout prisoners' speech, public information about prisons would come primarily from prison officials themselves." 230

224 AsYluMS, supra note 11, at xiii.

225 Id. at 41 (describing how "one's economy of action can be disrupted [by] the obligation to request permission or supplies for minor activities").

226 Id. When formerly incarcerated poet and memoirist Dwayne Betts was first put in jail, he was not given a mattress, a phone call, or access to a shower for several days. He describes the position of having to beg for basic necessities: "I was begging and learning Prison 101. You could beg, but that just made you feel like the time was doing you, like you weren't in control of yourself. Worse than that, you could beg and still not get anything." Dwayne BetTs, A Question of FreEdom: A MeMOIR of LeARning, Survival, AND Coming of AGe IN PRISON 15 (2009).

227 See, e.g., Sharon Dolovich, Cruelty, Prison Conditions, and the Eighth Amendment, 84 N.Y.U. L. REV. 881, 912-13 (2009) (describing vulnerability to the prison administration as a generalized feature of incarceration).

228 Bianchi \& Shapiro, supra note 46, at 19-23.

229 Id. at 3 (arguing that prisoners' ability to speak is important to "restrain[ing] the power of prison officials"); id. at 22.

230 Id. at 22. 
The absence of public discussion extends to most of the policies that govern every aspect of prison life. Most prison rules and regulations are not subject to public notice and comment, foreclosing a common avenue for the public to participate in governance. ${ }^{231}$ Even in states that permit public comment on prison regulations, layers of institutional decisions and directives - many informally made - are not considered regulations subject to public comment. ${ }^{232}$ Regulations about phone calls, mail, visits, and other forms of communication, for example, usually are exempt from notice and comment under the Administrative Procedure Act and also difficult to reach in legal challenges. ${ }^{233}$ This inability to participate in rulemaking undermines "transparency, accountability, and democratic participation." 234 If comment is not permitted and grievances are ignored or punished, few obvious channels for selfadvocacy remain in the political sphere.

The absence of the voices of incarcerated people reduces and distorts the knowledge base of those of us who are not incarcerated but who engage in democratic activities, like voting, reading news about criminal legal practices, and sharing our views with elected officials. ${ }^{235}$ To provide a concrete example, hearing from multiple people incarcerated in a prison in which there is a severe COVID-19 outbreak could help outsiders determine whether the infections were unavoidable or, instead, the result of inadequate safety measures and overcrowding. Deciding whether a COVID-19 death is the product of unavoidable misfortune or the product of systemic failure often requires obtaining information from multiple sources in addition to prison officials. The accounts of incarcerated people are thus vital to evaluating the prison as a public institution.

The value of speaking out goes beyond improving accountability and public debate. To the extent that prisons and jails function to create a class of people outside of the bounds of normal citizenship, they degrade our sense of democracy. Both incarcerated people and people who bear the mark of criminal convictions have been

231 Twenty-eight states limit or exclude their Departments of Correction from the state administrative procedure act, which means no notice and comment period is provided. Shay, supra note 75, at 347-48. Nevada, for example, completely exempts the Department of Corrections from the notice and comment requirements of its administrative procedure act. NEV. Rev. STAT. AnN. $\S$ 233B.039(1)(b) (LexisNexis 2007).

232 Shay, supra note 75 , at 350.

233 See, e.g., Massey v. Sec'y, Dep't. of Pub. Safety \& Corr. Servs., 886 A.2d 585, 598, 602 (Md. 2005) (internal rules that do not affect fundamental rights of the public are exempt from state's administrative procedure act regulations requirements).

234 Shay, supra note 75 , at 362.

235 Bianchi \& Shapiro, supra note 46, at 3 (according to "democracy legitimation theory, unrestrained prison censorship excludes prisoners' voices from the discussion of political and public issues that is central to facilitating democratic decision-making"); Whitney v. California, 274 U.S. 357, 375 (1927) (Brandeis, J., concurring) (political speech is protected under the First Amendment in part because "the greatest menace to freedom is an inert people; that public discussion is a political duty"). 
described as civilly dead, or as members of a second tier of "carceral citizenship."236 Moreover, the confluence of slavery, convict leasing, and lynching has created a historical legacy manifest in high rates of incarceration for Black men and women, who are then doubly victimized by the second-class citizen (or non-citizen) status experienced by incarcerated people. ${ }^{237}$

There is a danger of authoritarian spread from prisons. Approximately 2.3 million people in the U.S. live in this second tier of citizenship in which their right to protest and organize is severely curtailed, ${ }^{238}$ The prisons, jails, and detention facilities constitute an archipelago of autocracy in our midst. The sheer number of people epistemically limited by carceral conditions within a nation promising free speech and open political participation should raise democratic concerns. Indeed, it should prod us to ask what Angela Davis queries: what is the "version of democracy to which we are asked to consent"? 239

\section{CONCLUSION}

The anecdotal evidence of prison strikes and protests in the past eight years suggests that the political life of incarcerated people is alive and well. Even before the COVID-19 pandemic, the U.S. saw a resurgence in incarcerated activism. For example, thousands of prison laborers in five states went on strike to demand the right to form unions on September 9, 2016 - the anniversary of the Attica prison uprising. ${ }^{240}$ And, the prison strikes in 2018 were perhaps the most widespread prison strikes in decades. ${ }^{241}$ COVID-19 gave momentum to a twenty-first century wave of prisoner activism, with 119 documented protests within the first three months of the pandemic. ${ }^{242}$

236 Reuben J. Miller \& Amanda Alexander, The Price of Carceral Citizenship: Punishment, Surveillance, and Social Welfare Policy in an Age of Carceral Expansion, 21 MicH. J. RACE \& L. 291, 297 (2016).

237 DAvis, supra 14, at 49, 92.

238 See Wendy Sawyer \& Peter Wagner, Mass Incarceration: The Whole Pie 2020, PrISON PoL'Y. INITIATIVE (Mar. 24, 2020), https://www.prisonpolicy.org/reports/pie2020.html (illustrating the distribution of approximately 2.3 million incarcerated people in prisons, jails, and detention facilities)

239 DAVIS, supra note 14 , at 43.

240 Mike Elk, The Next Step for Organized Labor? People in Prison, The Nation (July 11, 2016), https://www.thenation.com/article/archive/the-next-step-for-organized-labor-people-in-prison/.

241 Nicole Lewis, What's Really Happening With the National Prison Strike?, THE MARSHALL PROJECT (Aug. 24, 2018), https://www.themarshallproject.org/2018/08/24/what-s-really-happeningwith-the-national-prison-strike [https://perma.cc/YRR3-9AUF].

242 Perilous has published an account of the first 90 days of prisoner COVID-19 activism. First 90 Days of Prisoner Resistance to COVID-19: Report on Events, Data, and Trends, PERILOus Chron. (Nov. 12, 2020), https://perilouschronicle.com/2020/11/12/COVID-prisoner-resistance-first-90-daysfull-report/. 
Just as the prison activism of the late 1960s and early 1970s was influenced by the civil rights movement, the Black Panther Party, and anti-war activism outside of the prison, ${ }^{243}$ the increased activism through both the Black Lives Matter movement and the immigrants' rights movement may similarly increase activism within jails and prisons. The first impact of the pandemic was the enforcement of lockdowns which, as discussed earlier, limit organizing efforts by limiting communication and movement. Nevertheless, protests increased over 2018 rates. The lockdowns will not last forever. Another wave of prison activism may follow.

It remains to be seen whether the new wave of incarcerated activism will lead to further repression, as it did in the 1970s, or to greater participation in political life for incarcerated people. I harbor the hope that speech from prison will not always be met with repression, and that the ability of incarcerated people to participate in public discourse and to organize in political groups will help not just incarcerated people but democracy as well.

243 ThOMPSON, supra note 37, at 14 (describing how many of the incoming prisoners were "young, politically aware, and determined to speak out when they saw injustices in the facility" and describing the young, activist prisoners as "black and brown youth who had been deeply impacted by the civil rights struggles of this period as well as by the writings of Malcolm X, Mao, and Che Guevara"). 